\title{
Procedimentos de biossegurança adotados por profissionais prestadores de serviços de manicure, pedicure, tatuagem, piercing e maquiagem definitiva no município de Jacareí-SP
}

Andréia Ferreira Diniz Cortelli

Dissertação apresentada ao Programa de Pós-Graduação em Saúde Pública da Faculdade de Saúde Pública da Universidade de São Paulo para obtenção do título de Mestre em Ciências.

Área de Concentração: Serviços de Saúde Pública

Orientador: Prof. Dr. Glavur Rogério Matté

São Paulo 
É expressamente proibida a comercialização deste documento tanto na sua forma impressa como na eletrônica. Sua reprodução total ou parcial é permitida exclusivamente para fins acadêmicos e científicos, desde que na reprodução configure a identificação do autor, título, instituição e ano da dissertação. 


\section{Dedicatória}

Ao meu esposo Fernando, pelo incentivo e pela compreensão durante a realização deste trabalho.

Aos meus pais, Alair e Dartier, pelo amor e cuidado dedicado a mim durante toda minha vida e pelo grande auxílio durante o período de realização deste estudo.

Aos meus filhos Pietro e Heitor, por existirem, tornando minha vida melhor. 


\section{Agradecimentos}

A Deus pelo dom da vida e por capacitar-me nesta jornada.

Ao Prof Dr Glavur Rogério Matté, pela orientação, permitindo que eu pudesse realizar com liberdade este trabalho.

A minha mãe Alair pela compreensão e cuidado comigo e com meus filhos.

A minha tia Zilda pela ajuda e cuidado com Pietro e Heitor durante a realização deste trabalho.

Aos colegas do Departamento de Vigilância à Saúde, especialmente João José Ferrari, Rodrigo Guimarães e Ricardo Buchaul, Andrezza Remondini pelo apoio e ajuda, sempre solícitos e prestativos.

Aos colegas Maria Luiza Arice, Marquirio Trindade e Vera Lúcia Barbosa professores da Escola Chico Ferreira, pelo auxílio e orientação na elaboração do texto.

Aos profissionais de embelezamento do município de Jacareí, pela colaboração com este trabalho.

A todas as pessoas que, direta ou indiretamente, colaboraram para a realização deste trabalho, a minha gratidão. 


\section{RESUMO}

Introdução - Práticas de embelezamento, como a tatuagem, a maquiagem definitiva, o piercing e a retirada de cutículas são comuns entre os brasileiros e frequentes nas diversas classes sociais, entre indivíduos de idades variadas e de ambos os sexos. Podem expor profissionais e usuários ao contato de agentes infecciosos veiculados pelo sangue, representando riscos de transmissão de doenças como hepatite B, hepatite C, AIDS e lesões dermatológicas. Objetivo - Investigar os procedimentos de biossegurança adotados pelos profissionais de embelezamento, manicure, pedicure, tatuagem, piercing e maquiagem definitiva no município de Jacareí-SP. Métodos - Foi utilizada uma abordagem descritiva e observacional de corte transversal. A coleta de dados foi realizada entre maio e junho de 2011. Quarenta profissionais foram entrevistados, 20 entrevistas foram realizadas em estabelecimentos localizados no centro da cidade e 20 em estabelecimentos nos dez bairros mais populosos do município. Utilizou-se questionário para avaliar conhecimentos e atitudes dos profissionais, bem como um formulário para a observação dos procedimentos destes profissionais e estrutura física dos estabelecimentos. Resultados - Verificou-se falta de conhecimento sobre biossegurança pelos profissionais, além do mais, a regulamentação destes serviços era deficiente. Embora 55\% dos profissionais tenham realizado treinamento, os procedimentos e a infra-estrutura dos estabelecimentos foram favoráveis à transmissão de doenças. Sobre os processos de limpeza, desinfecção e esterilização de instrumentais, nenhum dos entrevistados sabia o tempo e a temperatura ideal para a esterilização, 57,5\% tinham equipamento inadequado para sua realização e $80 \%$ não tinham termostato ou termômetro no equipamento para a conferência da temperatura. Quanto à percepção do risco, apenas 57,5\% acreditavam que poderiam transmitir doenças infecciosas durante sua prática profissional. Quarenta e cinco por cento dos entrevistados relataram que já tiveram contato com sangue sem usar luvas. Outro problema observado foi a reutilização de materiais descartáveis. Apenas 7,5\% dispunham de pia para lavar as mãos junto ao local de atendimento ao cliente, somente $10 \%$ possuíam área específica para a esterilização de instrumentais e 2,5\% pia exclusiva para a limpeza de materiais. Conclusões - É necessário oferecer 
formação de qualidade sobre boas práticas de biossegurança a esses profissionais, além de normas claras e diretrizes pormenorizadas para a prevenção de infecções nesses serviços, bem como a melhoria da vigilância nesses estabelecimentos.

Descritores em português: biossegurança, tatuagem, piercing corporal, manicure, pedicure, maquiagem definitiva, vigilância sanitária 


\section{ABSTRACT}

Introduction - Beautification practices such as tattooing, permanent makeup, piercing and removal of cuticles are common and frequent among Brazilians in the various social classes, between individuals of different ages and both sexes. Professionals and many exposed users to the contact of blood-borne infectious agents, representing risks of transmitting diseases such as hepatitis $\mathrm{B}$, hepatitis $\mathrm{C}$, AIDS and skin lesions. Objective - To investigate biosafety procedures adopted by beauty professionals, manicure, pedicure, tattoo, piercing and permanent makeup in the city of Jacareí-SP. Methods - We used a descriptive, observational and crosssectional approach. The field research was conducted between May and June 2011. Forty professionals were surveyed, with 20 interviews conducted in establishments located in the city center and 20 in establishments in the ten most populated districts of the municipality. We used the questionnaire to assess knowledge and attitudes of professionals as well as a formulary for the observation of professional procedures and physical structure of establishments. Results - It has been found lack of knowledge on biosafety by the professionals and, in addition, the regulation of these services was uneffective. Although 55\% of professionals had attended training courses, the procedures and establishments infrastructure were favorable to disease transmission. Regarding the processes of cleaning, disinfection and sterilization of instruments, none of interviewed knew the ideal time and temperature for sterilization, $57.5 \%$ had inadequate equipment for its functioning and $80 \%$ had no thermostat or thermometer in the equipment for the checking of the temperature. As for the perception of risk, only $57.5 \%$ believed they could transmit infectious diseases during their professional practice. Forty-five percent of respondents reported having contact with blood without wearing gloves. Another problem observed was the reuse of disposables. Only $7.5 \%$ had a sink for hand washing near the place of customer service, only $10 \%$ had a specific area for sterilization of instruments and $2.5 \%$ had exclusive sink for the cleaning of materials.

Conclusion - It is necessary to provide quality training to these professionals on good biosafety practices and standards and detailed guidelines for the prevention of 
infections in these services as well as improvement of the surveillance of these establishments.

Descritores em inglês: biosafety, tattooing, piercing, manicure, pedicure, permanent makeup, health surveillance 


\section{ÍNDICE}

1 INTRODUÇÃO 16

1.1 HEPATITES VIRAIS 20

$\begin{array}{lll}1.2 & \text { AIDS } & 21\end{array}$

1.3 BIOSSEGURANÇA 23

1.4 HIGIENIZAÇÃO DAS MÃOS 24

1.5 EQUIPAMENTOS DE PROTEÇÃO INDIVIDUAL 25

1.6 INSTRUMENTOS E MATERIAIS UTILIZADOS NO 25 ATENDIMENTO AO CLIENTE

1.7 LIMPEZA 26

1.8 ESTERILIZAÇÃO 26

1.9 ACONDICIONAMENTO DE ARTIGOS 28

1.10 CONTROLE DA EFICÁCIA DA ESTERILIZAÇÃO 28

1.11 MANUTENÇÃO DE EQUIPAMENTOS 29

2 JUSTIFICATIVA 29

3 OBJETIVOS 30

3.1 OBJETIVO GERAL 30

3.2 OBJETIVOS ESPECÍFICOS 30

4 CARACTERIZAÇÃO DO MUNICÍPIO 31

5 METODOLOGIA 31 
5.2 PERÍODO DE REALIZAÇÃO DO ESTUDO 33

5.3 AMOSTRAGEM 33

5.3.1 Critérios de Inclusão e Exclusão 34

5.4 COLETA DE DADOS 34

5.5 ASPECTOS ÉTICOS 36

6 RESULTADOS E DISCUSSÃO 36

6.1 SITUAÇÃO CADASTRAL DOS SERVIÇOS DE 38 EMBELEZAMENTO JUNTO À VIGILÂNCIA SANITÁRIA DE JACAREÍ

6.2 DISTRIBUIÇÃO DOS SUJEITOS ENTREVISTADOS POR PROFISSÃO

6.3 CARACTERIZAÇÃO DOS PROFISSIONAIS 40 ENTREVISTADOS

6.4 CAPACITAÇÃO DOS PROFISSIONAIS ENTREVISTADOS 43

6.5 PERCEPÇÃO DO RISCO DE TRANSMISSÃO DE DOENÇAS 44 DURANTE O EXERCÍCIO PROFISSIONAL

6.6 EXPOSIÇÃO ACIDENTAL AO SANGUE 46

6.7 LAVAGEM DAS MÃOS 47

6.8 USO DE EQUIPAMENTOS DE PROTEÇÃO INDIVIDUAL 48

6.9 EQUIPAMENTOS USADOS PARA A ESTERILIZAÇÃO 51

6.9.1 Manutenção de Equipamentos Usados na Esterilização 53 
6.10 DESINFECÇÃO, LIMPEZA E ESTERILIZAÇÃO

DOS INSTRUMENTAIS

6.10.1 Controle em Processo da Esterilização

6.11 ACONDICIONAMENTO E ARMAZENAMENTO DE

MATERIAIS ESTÉREIS

6.12 MATERIAIS DE USO ÚNICO 56

6.13 ESTRUTURA FÍSICA DOS SERVIÇOS 57

PESQUISADOS

6.14 MATERIAIS ESTÉREIS $\quad 59$

6.15 ACONDICIONAMENTO E DESCARTE DE RESÍDUOS 60

6.16 LIMPEZA DO AMBIENTE 61

6.17 NÚMEROS DE INSTRUMENTAIS EXISTENTES NOS 61

SERVIÇOS DE EMBELEZAMENTO

7 NORMATIZAÇÕES QUE REGULAMENTAM OS 63

SERVIÇOS DE EMBELEZAMENTO

8 DISCUSSÃO GERAL 66

9 CONCLUSÕES

10 RECOMENDAÇÕES 68

11 REFERÊNCIAS

$\begin{array}{ll}\text { ANEXOS } & 79\end{array}$

Anexo 1- Questionário

Anexo 2- Roteiro Observacional 
Anexo 3- Termo de Consentimento Livre e Esclarecido

Anexo 4- Declaração do município de Jacareí

Anexo 5- Autorização do município de Jacareí

Anexo 6- Folheto: Orientações sobre prevenção de riscos à saúde em serviços de embelezamento

\section{CURRÍCULO LATES}




\section{Lista de Tabelas}

Tabela 1- Número de entrevistas realizadas com profissionais de embelezamento no centro e nos dez bairros mais populosos de Jacareí no período de maio a junho de 2011.

Tabela 2 - Distribuição dos entrevistados por categoria profissional, Jacareí, 2011.

Tabela 3- Distribuição dos profissionais de embelezamento entrevistados por gênero, Jacareí, 2011.

Tabela 4- Adesão dos profissionais de embelezamento entrevistados aos equipamentos de proteção individual, Jacareí, 2011.

Tabela 5- Equipamentos de esterilização presentes nos serviços de embelezamentos pesquisados, Jacareí, 2011. 


\section{Lista de Quadros}

Quadro 1- Principais temas encontrados nas respostas dos sujeitos dos serviços de embelezamento sobre os motivos de usarem equipamentos de proteção individual e o número de vezes que eles apareceram, Jacareí, 2011.

Quadro 2 - Justificativa dos profissionais de embelezamento entrevistados que reutilizavam luvas descartáveis, Jacareí, 2011.

Quadro 3 - Estrutura física dos serviços de embelezamento pesquisados, Jacareí, 2011. 


\section{Lista de Figuras}

Figura 1- Distribuição dos profissionais de embelezamento entrevistados por faixa etária, Jacareí, 2011.

Figura 2- Distribuição dos profissionais de embelezamento por escolaridade, Jacareí, 2011.

Figura 3- Distribuição dos profissionais de embelezamento entrevistados por tempo de exercício de profissão, Jacareí, 2011. 


\title{
Siglas Utilizadas
}

\author{
AIDS - $\quad$ Síndrome da Imunodeficiência Adquirida \\ ANVISA - $\quad$ Agência Nacional de Vigilância Sanitária \\ CDC - $\quad$ Center for Disease Control \\ CVS - $\quad$ Centro de Vigilância Sanitária \\ DST - $\quad$ Doença Sexualmente Transmissível \\ HBV - Vírus da Hepatite B \\ HCV - Vírus da Hepatite C \\ HIV - Vírus da Imunodeficiência Humana \\ IBGE - $\quad$ Instituto Brasileiro de Geografia e Estatística \\ NR - $\quad$ Norma Regulamentadora \\ SIVISA - $\quad$ Sistema de Informações em Vigilância Sanitária \\ SS - $\quad$ Secretaria de Saúde \\ SUS - $\quad$ Sistema Único de Saúde
}




\section{INTRODUÇÃO}

Práticas de embelezamento, como a tatuagem, a maquiagem definitiva, o piercing e a retirada de cutículas podem ser considerados um fenômeno social e coletivo. Populares entre os brasileiros, são comuns e frequentes nas diversas classes sociais, entre indivíduos de idades variadas e de ambos os sexos.

Os cuidados com a aparência e o culto ao corpo sempre estiveram presentes na existência humana. $O$ ato de tatuar e perfurar o corpo para a implantação de adornos é comum desde a antiguidade. Existem evidências de práticas como a tatuagem desde os períodos paleolítico e neolítico, como o homem de gelo, cinco mil e trezentos anos antes de Cristo, que tinha linhas, cruzes e faixas tatuadas (SOUZA, 2001).

Os ideais de beleza se tornaram indissociáveis da idéia de prestígio e sucesso. A forte influência da sociedade, principalmente da mídia, tem levado a população a buscar incessantemente os padrões estabelecidos.

No Brasil, a indústria de produtos de higiene pessoal, perfumaria e cosméticos ao longo dos últimos anos tem demonstrado crescimento bem mais vigoroso que o restante da indústria geral, sendo o país, o terceiro maior mercado consumidor de produtos para beleza no mundo, perdendo apenas para Estados Unidos e Japão (ABIHPEC, 2012). Tal fato demonstra a valorização e o cuidado do brasileiro com seu corpo e sua aparência. Contudo, nessa exacerbada valoração da estética, os riscos à saúde presentes nas práticas de embelezamento não são considerados.

Já a tatuagem, tradicional prática popular, tem como objetivo pigmentar a pele. Para isso, realiza procedimentos invasivos que consistem na introdução intradérmica de substâncias corantes por meio de agulhas (SÃO PAULO (ESTADO), 1999).

A maquiagem definitiva, também chamada de dermopigmentação, é definida como a implantação de pigmentos (corantes) na epiderme com auxílio de agulhas apropriadas e um aparelho denominado dermógrafo, sendo uma modalidade da tatuagem (SANDERSON et al., 2009). 
A manicure e a pedicure são trabalhadoras nos serviços de embelezamento e higiene, cuidam da beleza das mãos e pés (BRASIL, 2002a). Segundo a Classificação Brasileira de Ocupações do Ministério do Trabalho, para a atuação destes profissionais é necessário, no mínimo, o ensino fundamental incompleto, curso de qualificação e até um ano de experiência profissional (BRASIL, 2002b). No entanto, não existem cursos regulamentados para formá-los.

Já o tatuador, o maquiador definitivo e o piercer, perfurador do corpo para a colocação de piercings, não são contemplados pela Classificação Brasileira de Ocupações do Ministério do Trabalho, além disso, também não existem cursos oficiais para a formação destes profissionais.

É extremamente relevante, para a prestação de serviços seguros e prevenção de riscos e agravos à saúde, a formação e capacitação destes trabalhadores. A literatura revela que eles não são capacitados para realizarem etapas como a limpeza e esterilização dos instrumentais utilizados (SILVA et al., 2007). Além do mais, grande parte dos profissionais de embelezamento não observa as normas de biossegurança (HELLARD et al., 2003).

Em suma, não há órgãos de classe que autorizem e regularizem o exercício destas profissões, sendo que na prática, o desenvolvimento destas atividades não requer formação específica.

As profissões de tatuador, piercer e maquiador definitivo não são formalizadas e as profissões de manicure e pedicure só foram reconhecidas no Brasil em janeiro de 2012 pela Lei 12592 (BRASIL, 2012).

Considerando os riscos à saúde presentes nessas atividades, os usuários e trabalhadores dos serviços de embelezamento devem ter sua saúde protegida e, compete à Vigilância Sanitária desenvolver ações que sejam capazes de eliminar, diminuir ou prevenir riscos à saúde e intervir nos problemas sanitários decorrentes da prestação destes serviços (BRASIL, 1990), assim, cabe à vigilância controlar as condições sanitárias em que os serviços de embelezamento são realizados e também promover adesão às normas de biossegurança. 
A Vigilância Sanitária pode ser definida como um conjunto de ações no âmbito das práticas de saúde coletiva, assentadas em várias áreas do conhecimento técnico-científico e em bases jurídicas que lhe conferem o poder de normatização, educação, avaliação e de intervenção, e que têm por objetivo controlar e garantir a qualidade dos processos tecnológicos utilizados na produção e reprodução das condições de vida, trabalho e saúde dos cidadãos. A Vigilância Sanitária, sob essa perspectiva, é um forte instrumento para a melhoria da qualidade de vida da população (EDUARDO, 1998).

A Lei $n^{\circ}$ 8080, que regula o Sistema Único de Saúde, estabelece além da Vigilância Sanitária, a descentralização das ações de saúde para estados e municípios (BRASIL, 1990).

Sendo assim, o Sistema Nacional de Vigilância Sanitária, integrante do Sistema Único de Saúde, opera de forma integrada e descentralizada em todo o território nacional. É coordenado pela Agência Nacional de Vigilância Sanitária, ANVISA, que possui a função de regulamentar e executar ações de abrangência nacional.

A ANVISA, devido ao processo de descentralização, enfatiza suas ações nas atividades de alta complexidade, cabendo aos Estados e Municípios as atividades de fiscalização e regulamentação complementares, nos seus respectivos âmbitos de atuação.

Dentro dos princípios da hierarquização e de descentralização das ações de saúde e segundo o modelo de organização proposto pelo SUS, todas as esferas de governo têm atribuições de normatizar e fiscalizar ações de saúde em caráter complementar e não contraditório.

Os serviços de embelezamento se enquadram em serviços de interesse à saúde e são considerados serviços de baixa complexidade, apesar dos riscos presentes nessas atividades não serem pequenos.

Procedimentos invasivos como a perfuração da pele, cartilagem e mucosas são próprios das atividades de tatuagem, piercing e maquiagem definitiva, sendo que sangramentos estão sempre presentes durante essas práticas. Por outro lado, na retirada de cutículas, o contato com sangue é acidental, 
porém comum. A exposição ao sangue oferece riscos à saúde de clientes e profissionais.

Vale ressaltar que a oferta e procura por serviços de manicure e pedicure é muito maior quando comparada à busca de tatuagem, piercing e maquiagem definitiva. São serviços utilizados com maior frequência pela população, tornando a exposição ao sangue muito comum durante a realização da atividade.

Estudo realizado por JOHNSON et al. (2001) com 120 estabelecimentos de manicure e pedicure no Canadá, demonstrou que $60 \%$ destes serviços apresentavam riscos de transmissão de doenças infecciosas.

WORP et al. (2006) relataram recentemente em Amsterdã dois casos de hepatite B aguda, sendo a fonte mais provável o mesmo estúdio de unhas.

Comumente, durante os procedimentos de estética, os instrumentais utilizados são contaminados com sangue da pessoa atendida e, se não esterilizados adequadamente podem agir como meio de transmissão parenteral dos vírus das hepatites B e C (MARIANO et al., 2004).

Os municípios têm um papel relevante sobre esse segmento, pois é atribuição da Vigilância Sanitária local a fiscalização e a orientação dos serviços de manicure, pedicure, tatuagem, piercing e maquiagem definitiva.

Estudo realizado no Recife mostrou que gabinetes de tatuagem e piercing não inspecionados pela Vigilância Sanitária local apresentavam maior deficiência na prevenção e controle de transmissão de doenças quando comparados aos inspecionados (SILVA et al., 2007).

Embora doenças infecciosas como AIDS e hepatites B e C sejam mais frequentemente transmitidas pela via sexual, elas podem ocorrer por meio da exposição percutânea ao sangue. Portanto, serviços de embelezamento que não obedecem às normas de biossegurança e não adotam procedimentos adequados de desinfecção, limpeza e esterilização de materiais perfurocortantes podem veicular essas doenças e, ainda, provocar lesões dermatológicas (JOHNSON et al. ,2001). A transmissão pode acontecer de profissional para cliente, entre clientes e de cliente para profissional. 
A literatura revela que têm ocorrido surtos de hepatite B em estúdios de unhas e também com a utilização de agulhas contaminadas em serviços de acupuntura e piercing (JOHNSON et al., 2001; WORP et al., 2006).

Vários estudos epidemiológicos realizados em indivíduos com infecção crônica pelo vírus da hepatite C (HCV) relatam a associação desta infecção com a tatuagem (WORP et al., 2006).

JOHNSON et al. (2001) e WEBER (2001) também relacionam serviços de embelezamento com a transmissão de hepatite B, HIV, sífilis e verrugas.

No Brasil, as doenças infectocontagiosas constituem ainda um sério desafio para a saúde pública. A grande importância destas doenças é devida não só ao número elevado de pessoas infectadas e às suas complicações, mas também à difícil identificação dos portadores assintomáticos.

Não foram encontrados dados disponíveis no Brasil referentes ao número de casos de transmissão de doenças infecciosas em decorrência da utilização de serviços de embelezamento.

\subsection{HEPATITES VIRAIS}

As hepatites podem ser agrupadas de acordo com o modo de transmissão em: fecal-oral (vírus A e E) e parenteral (vírus B, C, D); mas existem no mínimo sete tipos de vírus caracterizados: A, B, C, D, E, G e TT. Os vírus A, B e C são os responsáveis pela grande maioria das formas agudas de infecção (FERREIRA e SILVEIRA, 2004).

Dentre as hepatites virais transmitidas pela via parenteral, está a hepatite B, transmitida, sobretudo, pela via sexual. O vírus da hepatite B (HBV) pode ser transmitido por solução de continuidade (pele e mucosas); relações sexuais desprotegidas; transfusão de sangue e hemoderivados; por compartilhamento de agulhas e seringas; tatuagens, piercings, procedimentos odontológicos, médicos ou cirúrgicos quando as normas de biossegurança não são observadas; 
transmissão vertical e contatos domiciliares (FERREIRA e SILVEIRA, 2004; BRASIL, 2008).

Sabe-se hoje que o HBV é aproximadamente 100 vezes mais infectante do que o HIV e dez vezes mais que o HCV (CDC-Center for Disease Control, 2003).

Também a transmissão do vírus da hepatite C (HCV) também ocorre principalmente por via parenteral. A transmissão sexual é pouco freqüente. Em um percentual significativo de casos, não é possível identificar a via de infecção (BRASIL, 2008).

A prevalência do $\mathrm{HCV}$ com exatidão é desconhecida no nosso país. Os indivíduos considerados de risco são aqueles que receberam transfusões de sangue e/ou hemoderivados antes de 1992, usuários de drogas intravenosas, pessoas com tatuagens e piercings, alcoólatras, portadores de HIV, transplantados, hemodialisados, hemofílicos, presidiários e sexualmente promíscuos (BRASIL, 2008).

Hepatites virais têm grande importância pelo número de indivíduos atingidos e pela possibilidade de complicações das formas agudas, de médio e longo prazo quando da cronificação (BRASIL, 2008). Elas podem ser transmitidas em qualquer situação em que sangue contaminado é transferido entre indivíduos.

Os vírus causadores das hepatites determinam uma ampla variedade de apresentações clínicas, de portador assintomático, hepatite aguda ou crônica, até cirrose e carcinoma hepatocelular. A identificação de portadores assintomáticos de doenças infecciosas crônicas é difícil e onerosa; ademais, o número de pacientes infectados é incerto, e o esclarecimento dos agentes causadores é realizado de maneira insuficiente (FERREIRA e SILVEIRA, 2004).

\subsection{AIDS}

A Síndrome da Imunodeficiência Adquirida, AIDS, se disseminou pelo mundo tornando-se um dos maiores desafios de saúde pública nas últimas três 
décadas. O causador da AIDS é o vírus da Imunodeficiência Humana, conhecido como HIV. A transmissão da doença pode ocorrer pelas relações sexuais desprotegidas, transfusão de sangue contaminado, de mãe para filho durante a gestação, no parto ou aleitamento materno, e ainda, por via parenteral: compartilhamento de agulhas e seringas, tatuagens, piercings, procedimentos odontológicos ou cirúrgicos, etc. (BRASIL, s.d.).

Os infectados pelo HIV apresentam progressivo comprometimento imunológico, predisposição a neoplasias e ao surgimento de diversas infecções oportunistas que trouxeram elevada morbimortalidade para os doentes de AIDS, sendo estes elementos marcadores da síndrome (CHRISTO, 2010).

Podem ocorrer manifestações como pneumocistose, sarcoma de Kaposi, candidíase bucal, leucoplasia pilosa, doenças periodontais associadas ao HIV e linfoma não-Hodgkin (NOCE et al., 2005).

Além disso, manifestações otorrinolaringológicas podem ocorrer em cerca de 40 a 90\% dos casos de AIDS, sendo a deficiência auditiva a mais freqüente (CARVALHO ET al., 2001).

Também são muito comuns manifestações clínicas no Sistema Nervoso Central. Dentre as manifestações neurológicas ligadas diretamente ao HIV estão os transtornos da função cognitiva que causam déficits dos processos mentais tais como atenção, aprendizado, memória, rapidez do processamento de informações, capacidade de resolução de problemas; sintomas sensoriais, motores e a demência associada ao HIV. Outras causas de danos cognitivos e psiquiátricos associados ao HIV são as sequelas relacionadas às doenças oportunistas do Sistema Nervoso Central, como neurotoxoplasmose, meningite tuberculosa e neurocriptococose (CHRISTO, 2010).

Entre a aquisição do HIV e a manifestação da doença, podem se passar anos, sendo assim, o vírus HIV pode ser transmitido não somente pela pessoa que já está desenvolvendo os sintomas da doença, mas também pelo portador assintomático.

Estudo realizado no Rio Grande do Sul avaliou o conhecimento de indivíduos de meia idade sobre HIV/AIDS e demonstrou que 65,2\% dos 
entrevistados desconheciam a fase assintomática da infecção (LAZZAROTTO et al., 2010).

Neste período, o portador assintomático, tendo ou não conhecimento de sua situação, e apesar de ainda não apresentar complicações associadas à infecção, continua sendo transmissor do HIV.

Por certo, o desconhecimento da fase assintomática do HIV juntamente com a falta de cuidados quanto à biossegurança durante a realização dos serviços de manicure, pedicure, tatuagem, piercing e maquiagem definitiva colocam profissionais e clientes em situação vulnerável para a contaminação e transmissão do vírus.

\subsection{BIOSSEGURANÇA}

A biossegurança é um processo funcional e operacional e, pode ser definida como um conjunto de ações de extrema importância nos serviços de saúde e também nos serviços de interesse à saúde. Aborda medidas de controle de infecções visando à proteção de trabalhadores e usuários desses serviços. Exerce ainda um papel fundamental na promoção da consciência sanitária na comunidade onde atua, sobre a importância da preservação do meio ambiente, na manipulação e no descarte de resíduos químicos tóxicos e infectantes e da redução de riscos à saúde (OPPERMANN e PIRES, 2003).

A biossegurança enfatiza suas ações na prevenção, diminuição ou até mesmo na eliminação dos riscos inerentes a cada atividade. Para isso, inclui o uso de barreiras ou equipamentos de proteção individual, a prevenção de acidentes com materiais perfurocortantes e procedimentos adequados de descontaminação, esterilização e destino dos resíduos (NARESSI et al., 2004). Contempla desde infra-estrutura até a qualificação de profissionais.

É um processo progressivo que não inclui conclusão em sua terminologia, devendo ser sempre atualizado e supervisionado (OPPERMANN e PIRES, 2003). 
O Center for Disease Control, CDC, publicou as precauções universais, que são recomendações aos profissionais de saúde que têm como objetivo minimizar o risco de contaminação dos profissionais de saúde com HIV ou hepatite B, no caso de contato com sangue ou fluidos corporais contaminados. No início eram denominadas "medidas de precaução universais" e atualmente são chamadas de "precauçõespadrão" (CDC - Center for Disease Control, 1987;1998). São medidas usadas para diminuir o risco de exposição dos trabalhadores a doenças infecciosas.

O conceito de precaução-padrão parte da premissa de que todo cliente pode estar potencialmente infectado, sendo assim, o profissional deve se prevenir com medidas de barreira sempre que houver possibilidade de contato com sangue ou fluidos corporais. No entanto, as medidas de precaução-padrão podem minimizar, mas não eliminam o risco ocupacional (LOPES et al., 1999).

De modo geral, pode-se afirmar que as medidas de precaução-padrão estão inclusas dentro da biossegurança e que, devem ser observadas por profissionais de embelezamento, que em seu trabalho entram em contato com sangue ou fluidos corporais de clientes.

\subsection{HIGIENIZAÇÃO DAS MÃOS}

As mãos constituem a principal via de transmissão de microorganismos durante o serviço prestado, pois a pele é um possível reservatório de diversos microorganismos que podem se transferir de uma superfície para outra, por meio de contato direto, pele com pele, ou indireto, através do contato com objetos e superfícies contaminados. A higienização das mãos é uma medida simples para prevenção das infecções relacionadas à assistência à saúde.

As mãos podem ser higienizadas utilizando-se: água e sabão, preparação alcoólica e antisséptico (ANVISA, 2007a).

De acordo com o Regulamento Técnico para planejamento, programação, elaboração e avaliação de projetos físicos de estabelecimentos assistências de saúde, a provisão de recursos para a higienização das mãos por meio de lavatórios ou pias 
para uso da equipe de assistência é obrigatória sempre que existir paciente examinado, manuseado, tocado, medicado ou tratado (ANVISA, 2002).

\subsection{EQUIPAMENTOS DE PROTEÇÃO INDIVIDUAL}

O Ministério do Trabalho, por meio de Portaria 3214, de 1978, estabeleceu as Normas Regulamentadoras, conhecidas NRs (BRASIL, 1978). A NR 06 regulamenta os Equipamentos de Proteção Individual e considera-os como sendo todo dispositivo ou produto, de uso individual utilizado pelo trabalhador, destinado à proteção de riscos suscetíveis de ameaçar a segurança e a saúde no trabalho.

Portanto, é aconselhável, no atendimento aos clientes, o uso de luvas descartáveis combinadas com outros equipamentos de proteção individual que se façam necessários, como óculos, máscara e avental, caso exista a possibilidade de contato com sangue, fluidos corporais, secreções e excreções, pois eles funcionam como barreira protetora prevenindo a contaminação grosseira das mãos; assim como o uso de luvas de borracha para a realização de limpeza e desinfecção de materiais (ANVISA, 2000).

\subsection{INSTRUMENTOS E MATERIAIS UTILIZADOS NO ATENDIMENTO AO CLIENTE}

Os instrumentos e materiais reutilizáveis podem se tornar veículos de agentes infecciosos se não passarem por descontaminação após cada uso.

Baseados no risco potencial de transmissão de infecções, os instrumentais são classificados em artigos críticos, artigos semicríticos e artigos não críticos. Os artigos críticos são destinados à penetração através da pele e mucosas adjacentes, nos tecidos subepiteliais e no sistema vascular, bem como todos os que estejam diretamente conectados com este sistema. Eles devem ser esterilizados para satisfazer 
os objetivos a que se propõem. Os artigos semicríticos são destinados ao contato com a pele não-íntegra ou com mucosas íntegras e requerem desinfecção de médio ou de alto nível, ou esterilização, para ter garantida a qualidade do múltiplo uso destes. Os artigos não-críticos são destinados ao contato com a pele íntegra e requerem limpeza ou desinfecção de baixo ou médio nível, dependendo do uso a que se destinam ou do último uso realizado (MINISTÉRIO DA SAÚDE. SECRETARIA DE ASSISTÊNCIA À SAÚDE. 1994).

\subsection{LIMPEZA}

É o procedimento de remoção de sujidade e detritos de qualquer superfície para manter em estado de asseio os artigos, reduzindo a população microbiana. Ela deve preceder os procedimentos de desinfecção ou de esterilização, pois reduz a carga microbiana através da remoção da sujidade e da matéria orgânica presente nos materiais (ANVISA, 2000).

A limpeza pode ser realizada por meio de: fricção mecânica, utilizando produtos para esta finalidade, escova ou esponja; por meio de máquinas de ultrassom com detergentes/desencrostantes ou imersão completa do artigo em solução desinfetante; ou ainda, por meio de máquinas de limpeza com jatos de água quente ou detergente. (MINISTÉRIO A SAÚDE, SECRETARIA E ASSISTÊNCIA À SAÚDE. 1994).

É importante ainda ressaltar alguns cuidados como o enxágue dos instrumentais usando água potável e a realização da secagem de modo a evitar interferência da umidade.

\subsection{ESTERILIZAÇÃO}


É o processo de destruição de todas as formas de vida microbiana, ou seja, bactérias na forma vegetativa e esporuladas, fungos e vírus, mediante a aplicação de agentes físicos e químicos (ANVISA, 2000).

Os métodos de esterilização podem ser físicos e químicos. Dentre os físicos há o calor, sob a forma úmida e seca, que são os mais comumente utilizados nos serviços de embelezamento. São eles:

Vapor Saturado Sob Pressão - autoclave - é o processo de esterilização mais seguro, eficiente, rápido e econômico disponível. O mecanismo de esterilização pelo vapor saturado sob pressão está relacionado com o calor latente e o contato direto com o vapor, promovendo a coagulação das proteínas. Calor latente é o calor que um corpo "recebe" sem variação de temperatura e sim de estado físico. O vapor sob pressão, ao entrar em contato com a superfície fria dos materiais colocados na autoclave, se condensa liberando o calor latente, que é o responsável pela desnaturação dos microorganismos. A esterilização está fundamentada nesta troca de calor entre o meio e o objeto a ser esterilizado (ANVISA, 2000).

É necessário o estabelecimento de rotinas e procedimentos no preparo e no acondicionamento dos artigos a serem esterilizados, além do perfeito funcionamento do equipamento.

A combinação do tempo de exposição e da temperatura adotados nos ciclos de esterilização também é condição essencial para a garantia da eficácia deste processo (ANVISA, 2000).

Calor Seco - estufa ou forno de Pasteur - é realizada em estufas elétricas equipadas com termostato e ventilador. A circulação do ar quente e o aquecimento dos materiais acontecem de forma lenta e irregular, requerendo longos períodos de exposição e temperatura mais elevada do que o vapor saturado sob pressão, para se alcançar a esterilização. Este processo exige cuidados como propiciar a livre circulação do ar por toda a estufa e entre as caixas e observar rigorosamente a relação tempo de exposição e temperatura, a fim de assegurar a sua eficácia. O tempo de exposição deve ser considerado apenas quando a temperatura determinada for alcançada, sem incluir o tempo gasto para o aquecimento (ANVISA, 2000).

A utilização do calor seco não é a melhor opção para a esterilização de materiais, além de ser um método em desuso. 


\subsection{ACONDICIONAMENTO DE ARTIGOS}

O acondicionamento dos artigos deve ser feito com embalagens permeáveis ao vapor, além de resistentes a condições úmidas e secas, flexíveis e que não permitam a penetração do microorganismo após o processo de esterilização. Devem favorecer o fechamento ou selagem e apresentarem facilidade na abertura sem ocasionar risco de contaminação do seu conteúdo (ANVISA, 2000). É de extrema importância registrar o seu conteúdo, a data de esterilização e o prazo de validade desta.

\subsection{CONTROLE DA EFICÁCIA DA ESTERILIZAÇÃO}

A efetividade da esterilização deve ser realizada por meio de monitoramento do processo lançando mão de testes físicos, químicos ou biológicos no mínimo semanalmente (ANVISA, 2000; MINISTÉRIO DA SAÚDE, 1994).

Dentre os testes físicos está a avaliação de desempenho do esterilizador que serve para apontar as condições internas da autoclave. Essa avaliação envolve a observação dos parâmetros apresentados durante o processo, por meio de termômetro para a verificação da temperatura e manômetro para a verificação da pressão (MINISTÉRIO DA SAÚDE. SECRETARIA DE ASSISTÊNCIA À SAÚDE. 1994).

Outro teste é a qualificação térmica por termopares, que determina o tempo de penetração do calor dentro das embalagens. É utilizado após a instalação de autoclaves e estufas ou após grandes reparos desses equipamentos. No entanto, seu custo é muito alto (MINISTÉRIO DA SAÚDE. SECRETARIA DE ASSISTÊNCIA À SAÚDE. 1994).

Existe ainda a dosimetria de radiação que consiste na avaliação da quantidade de energia absorvida pelo material tratado. São utilizados dosímetros que indicam se a dose recebida é compatível com o processo de esterilização 
(MINISTÉRIO DA SAÚDE. SECRETARIA DE ASSISTÊNCIA À SAÚDE. 1994).

Dentre os testes químicos estão os indicadores químicos que servem para indicar falhas relacionadas à penetração do calor em estufas e autoclaves, além de ajudar na identificação de pacotes já esterilizados. Consiste em tiras de papel impregnadas com tinta termocrômica que mudam de cor quando expostas à temperatura e tempo recomendados pelo fabricante (MINISTÉRIO DA SAÚDE. SECRETARIA DE ASSISTÊNCIA À SAÚDE. 1994).

Outro teste químico é o teste de Bowie \& Dick que deve ser realizado no primeiro ciclo do dia da autoclave. Consiste numa folha que mostra a eficácia do processo por meio de sua coloração (MINISTÉRIO DA SAÚDE. SECRETARIA DE ASSISTÊNCIA À SAÚDE. 1994).

Os indicadores biológicos são os que melhor retratam o processo de esterilização, garantindo a sua segurança. Para isso utiliza-se um grande número de esporos bacterianos. A resposta biológica da segurança do processo é dada dentro de 1-3 horas (ANVISA, 2000).

\subsection{MANUTENÇÃO DE EQUIPAMENTOS}

Um programa de manutenção do equipamento deve ser estabelecido para assegurar o desempenho adequado do mesmo, além de aumentar a vida útil do equipamento (APECIH - ASSOCIAÇÃO PAULISTA DE ESTUDOS E CONTROLE DE INFECÇÃO HOSPITALAR, 2003). Além da manutenção corretiva também deve ser realizada a manutenção preventiva com aferição do equipamento.

\section{JUSTIFICATIVA}


Serviços de embelezamento podem expor profissionais e usuários ao contato de agentes infecciosos veiculados pelo sangue, representando riscos de transmissão de doenças como hepatite B, hepatite C, AIDS e lesões dermatológicas.

Atualmente, percebe-se que o costume de fazer tatuagem, maquiagem definitiva, retirar as cutículas e colocar piercing popularizou-se intensamente, aumentando a exposição da população ao risco de danos à saúde.

Considerando a inexistência da obrigatoriedade de qualquer formação para o exercício das profissões de manicure, pedicure, tatuagem, piercing e maquiagem definitiva é importante verificar a capacitação desses profissionais e relacioná-la com os procedimentos de biossegurança adotados por eles.

\section{OBJETIVOS}

\subsection{OBJETIVO GERAL}

Verificar as condições sanitárias em que são realizados os serviços de manicure, pedicure, tatuagem, piercing e maquiagem definitiva no município de Jacareí-SP.

\subsection{OBJETIVOS ESPECÍFICOS}

Pesquisar a formação e a capacitação dos profissionais no quesito biossegurança.

Averiguar o conhecimento dos entrevistados sobre o risco de transmissão de doenças infecciosas durante a realização de suas atividades profissionais.

Verificar a estrutura fisicofuncional dos serviços de embelezamento. 
Verificar também os procedimentos de biossegurança adotados pelos profissionais entrevistados.

\section{CARACTERIZAÇÃO DO MUNICÍPIO}

O município de Jacareí está localizado entre os dois principais centros urbanos do país, São Paulo e Rio de Janeiro. Possui uma área total de: $459.684 \mathrm{~km}^{2}$ (quatrocentos e cinquenta e nove e seiscentos e oitenta e quatro). A população estimada, segundo o IBGE, Instituto Brasileiro de Geografia e Estatística, em 2010 era de 211.214 (duzentos e onze mil e duzentos e quatorze) habitantes (IBGE Instituto Brasileiro de Geografia e Estatística, s.d.).

De acordo com o Sistema de Informações em Vigilância Sanitária, SIVISA, em novembro de 2010 havia apenas três serviços de tatuagem e piercing e doze salões de beleza cadastrados na Vigilância Sanitária Municipal, embora no Cadastro dos Estabelecimentos Tributados: Atividade Serviços de Embelezamento, do Setor de Tributos da Secretaria de Finanças do Município de Jacareí, obtido em outubro de 2010, existissem quatrocentos e onze estabelecimentos registrados. Na mesma época não havia nenhum serviço de maquiagem definitiva cadastrado no SIVISA.

Não foram encontradas informações sobre o total de profissionais de embelezamento atuantes no município de Jacareí na época da realização do estudo.

\section{METODOLOGIA}

Para o presente trabalho, adotou-se como definição da prática de implantação de piercing, a fixação de adornos no corpo humano, em áreas expostas, como orelhas e lábios ou até mesmo em áreas íntimas, realizada por 
meio da perfuração de uma região anatômica, introduzindo através da pele ou mucosa brincos, argolas, alfinetes e assemelhados.

Devido à grande variedade de tipos e marcas de esterilizadores, para diferenciar os mais comumente usados, estufas e "forninhos", foram observadas características externas desses equipamentos. Considerou-se estufa o esterilizador que apresentava interruptor, termostato e local para o termômetro de bulbo utilizado para a realização da aferição da temperatura (MINISTÉRIO DA SAÚDE. SECRETARIA DE ASSISTÊNCIA À SAÚDE. 2001; SÃO PAULO (ESTADO), 1995).

Foi caracterizado como "forninho", o equipamento que não possuía termostato e/ou local para aferir a temperatura com termômetro.

\subsection{TIPO DE ESTUDO}

Foram utilizadas, de forma complementar, recursos de pesquisa quantitativa e qualitativa. $O$ uso concomitante das duas abordagens foi necessário, pois há situações onde ambas são insuficientes para abarcar toda a realidade observada (MINAYO e SANCHES, 1993).

Por meio da abordagem quantitativa buscou-se a representatividade numérica da população definida possibilitando a generalização dos conceitos e, por meio da qualitativa, buscou-se o aprofundamento, uma compreensão mais abrangente do grupo estudado (MINAYO, 2004).

O estudo foi desenvolvido dentro de uma abordagem descritiva, pois, segundo GIL (2007) entre os objetivos da pesquisa descritiva está o levantamento de opiniões, atitudes e a descrição de características do grupo estudado. Foi utilizada abordagem transversal e também observacional, a qual pode ser utilizada em conjunto com outros métodos (GIL, 2007). 


\subsection{PERÍODO DE REALIZAÇÃO DO ESTUDO}

A coleta de dados foi realizada entre maio e junho de 2011.

Foi utilizado o cadastro de profissionais de embelezamento no SIVISA em 2010, e não o de outra época, pois foi quando também realizou-se o levantamento desses dados junto ao Setor de Tributos do município. Desse modo, foi possível a confrontação entre os serviços cadastrados, na mesma época, no SIVISA e no Setor de Tributos do município.

\subsection{AMOSTRAGEM}

A população estudada foi constituída por profissionais de manicure, pedicure, tatuagem, piercing e maquiagem definitiva atuantes no município de Jacareí, SP.

Não fizeram parte da amostra estudada neste trabalho os profissionais que atuam em sua própria residência, pois não possuem estabelecimento formal para atender seus clientes. Também não compuseram a amostra os profissionais ambulantes, pois prestam seus serviços no domicílio do cliente. Apesar de serem modalidades comuns, estes profissionais não foram incluídos nesta pesquisa devido ao fato de não se enquadrarem na metodologia do trabalho.

Foram realizadas quarenta entrevistas entre esses profissionais, ou seja, aproximadamente dez por cento do número de serviços de embelezamento existentes no município de acordo com o Cadastro dos Estabelecimentos Tributados: Atividade Serviços de Embelezamento, do Setor de Tributos da Secretaria de Finanças do Município de Jacareí, compondo assim a amostra de conveniência.

Metade das entrevistas foi realizada nos estabelecimentos localizados no centro da cidade, pois, por tratar-se de um município de médio porte e devido às características socioculturais, no centro há maior circulação de pessoas atraídas pela oferta variada de serviços e comércios concentrados numa única região. A maioria dos prestadores de serviços de embelezamento encontrava-se na região central. 
A outra metade foi realizada nos dez bairros mais populosos do município seguindo uma ordem decrescente, conforme Cadastro de População por Bairro obtido juntamente ao Serviço Autônomo de Água e Esgoto de Jacareí em novembro de 2010.

Em visita ao centro e aos bairros, foram identificadas as ruas principais onde estava localizado o comércio daquela região. Estas ruas foram percorridas e os serviços de embelezamento identificados.

Por bairro, foram escolhidos aleatoriamente dois estabelecimentos onde as entrevistas foram realizadas, perfazendo um total de dez bairros e vinte entrevistas.

Quando no estabelecimento selecionado havia mais de um profissional de manicure, pedicure, tatuagem, piercing ou maquiagem definitiva, entrevistou-se apenas um trabalhador, que se disponibilizou voluntariamente, pois, é comum entre profissionais de um mesmo serviço, haver o compartilhamento, além do mesmo ambiente, de práticas e atitudes.

\subsubsection{Critérios de Inclusão e Exclusão}

Foram considerados os seguintes critérios para inclusão do profissional na pesquisa:

1. Ser profissional de manicure, pedicure, tatuagem, piercing ou maquiagem definitiva com idade igual ou superior a 18 anos;

2. Consentir em participar e assinar o termo de consentimento livre e esclarecido, após esclarecimento verbal pela pesquisadora sobre os objetivos e a metodologia da pesquisa.

Para a exclusão do profissional, foram considerados os seguintes critérios:

3. Possuir idade inferior a 18 anos;

4. Não concordar em assinar o termo de consentimento livre e esclarecido.

\subsection{COLETA DE DADOS}

As entrevistas, semiestruturadas, foram realizadas, pela pesquisadora, face a face no próprio estabelecimento no período de maio a junho de 2011. 
Como instrumento de coleta dos dados foi utilizado questionário (anexo 1), composto por questões abertas e fechadas realizadas oralmente pela pesquisadora, sendo as respostas dos pesquisados transcritas imediatamente. Também foi utilizado roteiro observacional (anexo 2), preenchido de forma manual pela própria pesquisadora.

O questionário incluiu questões sobre fatos, conhecimentos e comportamentos. Por meio da aplicação do questionário obteve-se o relato, a fala dos profissionais e, através do roteiro observacional suas práticas foram verificadas. Esses instrumentos, linguagem e prática, e o confronto entre elas, são materiais primordiais para a investigação qualitativa (MINAYO e SANCHES, 1993).

As falas dos entrevistados foram usadas neste estudo exatamente da forma em que foram expressas por eles. Os temas de suas falas foram usados como dados e compuseram os resultados.

O questionário permitiu caracterizar os profissionais quanto à formação, idade, capacitação e tempo de profisssão. Permitiu também averiguar seus conhecimentos sobre transmissão de doenças infecciosas e riscos à saúde relacionados às suas atividades, e ainda, confrontar suas falas relacionadas às práticas de biossegurança com suas atitudes, observadas por meio do roteiro.

Ademais, por meio do roteiro observacional a pesquisadora verificou a estrutura física dos estabelecimentos e os procedimentos de biossegurança adotados pelos profissionais.

Tanto o questionário quanto o roteiro observacional foram baseados nos instrumentos utilizados por OLIVEIRA (2009) em seu estudo com manicures na cidade de São Paulo.

Não foi realizado pré-teste.

Ao final de cada entrevista foram fornecidas informações educativas sobre biossegurança e prevenção de doenças transmissíveis em serviços de embelezamento. Também foi entregue folheto com orientações sobre prevenção de riscos à saúde em serviços de embelezamento confeccionado pela própria pesquisadora (anexo 6).

O folheto, confeccionado pela pesquisadora, foi baseado nos seguintes materiais: "Orientações sobre prevenção de riscos à saúde em salões de beleza" elaborado pela COVISA, São Paulo, "Beleza com Segurança, guia técnico para profissionais" 
COVISA, São Paulo e "Guia de embelezamento saudável" Prefeitura de Santo André.

\subsection{ASPECTOS ÉTICOS}

O estudo foi submetido e aprovado pelo Comitê de Ética em Pesquisa da Faculdade de Saúde Pública da Universidade de São Paulo.

Todos os entrevistados foram convidados a participar voluntariamente do estudo. Anterior ao início das entrevistas foi realizada a leitura integral do Termo de Consentimento Livre e Esclarecido solicitando a anuência à pesquisa e assinatura nesse documento (anexo 3), conforme a Resolução n ${ }^{\circ}$ 196/96 do Conselho Nacional de Saúde.

O risco de constrangimento foi mínimo, pois a identidade do entrevistado foi preservada mantendo-se o anonimato. As informações obtidas através desta pesquisa são confidenciais ao Prof. Dr. Glavur Rogério Matté e a pesquisadora Andréia Ferreira Diniz Cortelli. Os resultados não foram e nem serão divulgados de forma a possibilitar a identificação dos participantes.

A pesquisadora é servidora pública do município de Jacareí e está lotada no Departamento de Vigilância à Saúde, junto à Vigilância Sanitária, porém não realiza fiscalização nem inspeções sanitárias nos serviços de embelezamento: manicure, pedicure, tatuagem, piercing e maquiagem definitiva, conforme declaração fornecida por este departamento (anexo 4). Possui autorização do município para a realização deste estudo (anexo 5).

\section{RESULTADOS E DISCUSSÃO}

Metade das entrevistas foi realizada nos estabelecimentos localizados no centro da cidade. A outra metade foi realizada nos dez bairros mais populosos do município seguindo uma ordem decrescente de acordo com o Cadastro de População 
por Bairro obtido juntamente ao Serviço Autônomo de Água e Esgoto de Jacareí em novembro de 2010, conforme demonstrado na Tabela 1.

Tabela 1- Número de entrevistas realizadas com profissionais de embelezamento no
centro e nos dez bairros mais populosos de Jacareí no período de maio a junho de
2011.

\begin{tabular}{lll}
\hline Bairros & N & $\%$ \\
\hline & & \\
Centro & 20 & 50 \\
Parque Santo Antônio & 02 & 05 \\
Cidade Salvador & 02 & 05 \\
Parque Meia Lua & 02 & 05 \\
Jardim Paraíso & 02 & 05 \\
Parque dos Príncipes & 02 & 05 \\
Bandeira Branca & 02 & 05 \\
Jardim Flórida & 02 & 05 \\
Jardim Santa Maria & 02 & 05 \\
Jardim Santa Marina & 02 & 05 \\
Vila Garcia & 02 & 05 \\
Total & $\mathbf{4 0}$ & $\mathbf{1 0 0}$
\end{tabular}

Dentre os profissionais entrevistados, tanto no centro da cidade quanto nos bairros, não foram constatadas diferenças quanto à idade, tempo de profissão, formação e capacitação dos mesmos, nem quanto aos seus conhecimentos e atitudes relacionados ao risco de transmissão de doenças infecciosas e à biossegurança.

Ainda, a estrutura fisicofuncional dos estabelecimentos visitados no centro da cidade e nos bairros é similar. 


\subsection{SITUAÇÃO CADASTRAL DOS SERVIÇOS PESQUISADOS JUNTO À VIGILÂNCIA SANITÁRIA}

Dos estabelecimentos pesquisados, apenas (13) 32,5\% possuíam cadastro junto à Vigilância Sanitária Municipal, sendo que a maioria dos cadastrados estava localizada no centro de Jacareí.

Foram observadas falhas nos processos e nos cuidados referentes à biossegurança nos serviços cadastrados assim como nos não cadastrados na Vigilância Sanitária de Jacareí.

No entanto, SILVA et al. (2006) observaram que os gabinetes de tatuagem e piercing não inspecionados pela Vigilância Sanitária em Recife apresentavam maior deficiência no processo de esterilização dos instrumentais quando comparados aos inspecionados pela Vigilância local.

O cadastro realizado pela Vigilância Sanitária Municipal e Jacareí consiste na apresentação pelo interessado de documentos solicitados e em uma vistoria realizada pela equipe de fiscalização. Caso necessário, a equipe de Vigilância Sanitária poderá retornar ao local para verificar o cumprimento de orientações realizadas durante a inspeção. Uma vez realizado o cadastro ele não precisa ser renovado, não sendo realizadas novas inspeções no estabelecimento.

$\mathrm{Na}$ época em que o estudo foi realizado, não existia busca ativa por esses serviços na Vigilância Sanitária do município, também, não eram realizadas inspeções de rotina para o acompanhamento desses serviços, eram apenas cadastrados os serviços que tomam a iniciativa em buscá-lo.

Considerando que esta pesquisa não encontrou diferença nos processos de trabalho e cuidados relacionados à biossegurança tanto nos estabelecimentos cadastrados quanto nos não cadastrados, pode-se concluir que o cadastro realizado pela Vigilância Sanitária não garante que processos como limpeza e esterilização sejam adequados.

Diferentemente, no setor de tributos de Jacareí, onde o número de serviços de embelezamento cadastrados é muito maior quando comparado ao número de serviços cadastrados existente na Vigilância Sanitária, existe a busca 
ativa por serviços tributáveis.

Para que haja mudança nessa situação é necessário que a Vigilância realize busca ativa pelos serviços de embelezamento e que sejam realizadas inspeções sanitárias com maior frequência, e não somente no momento do cadastro.

\subsection{DISTRIBUIÇÃO DOS SUJEITOS ENTREVISTADOS POR PROFISSÃO}

A população de estudo foi composta por 40 profissionais de embelezamento, sendo que 30 eram manicures e pedicures, 06 eram tatuadores e piercers simultaneamente, 03 eram somente tatuadores e 01 maquiadora definitiva, conforme disposto na Tabela 2. Apenas uma profissional de maquiagem definitiva e duas manicures/pedicures se recusaram a participar do estudo.

Tabela 2 - Distribuição dos entrevistados por categoria profissional, Jacareí, 2011.

Categoria profissional

$\%$

Manicure e pedicure

30

75

Tatuador e piercer simultaneamente

06

15

Tatuador

03

7,5

Maquiadora definitiva

01

2,5

TOTAL 
Os serviços de tatuagem, piercing e de maquiagem definitiva foram encontrados apenas na região central da cidade.

O número de manicures e pedicures entrevistadas foi três vezes maior do que o número total de tatuadores, piercers e maquiador definitivo pesquisados. Provavelmente, esse fato pode ser explicado pela maior oferta dos serviços de embelezamento das unhas quando comparados aos serviços de tatuagem, piercing e maquiagem definitiva, pois, muitos usuários fazem as unhas frequentemente. Além disso, unhas e cutículas não demoram a crescer e, as cores podem ser sempre trocadas e variadas, contudo, tatuagem e maquiagem definitiva, depois de realizadas dificilmente são removidas.

\subsection{CARACTERIZAÇÃO DOS PROFISSIONAIS ENTREVISTADOS}

Entre os tatuadores, piercers e maquiadores definitivos, apenas duas eram do sexo feminino e oito do sexo masculino, porém, todas as manicures e pedicures entrevistadas eram mulheres.

A Tabela 3 apresenta a distribuição dos profissionais de embelezamento entrevistados por gênero.

Tabela 3 - Distribuição dos profissionais de embelezamento entrevistados por gêne-
ro, Jacareí, 2011.

\begin{tabular}{lll}
\hline Sexo & N & $\%$ \\
\hline Feminino & 32 & 80 \\
Masculino & 08 & 20 \\
\hline TOTAL & & 100 \\
\hline
\end{tabular}


Dentre os entrevistados, $62,5 \%$ possuíam idade entre 26 e 40 anos, 22,5\% entre 18 e 25 anos e $15 \%$ de 41 a 55 . Não foram encontrados profissionais com idade superior a 55 anos, conforme representado na Figura 1.

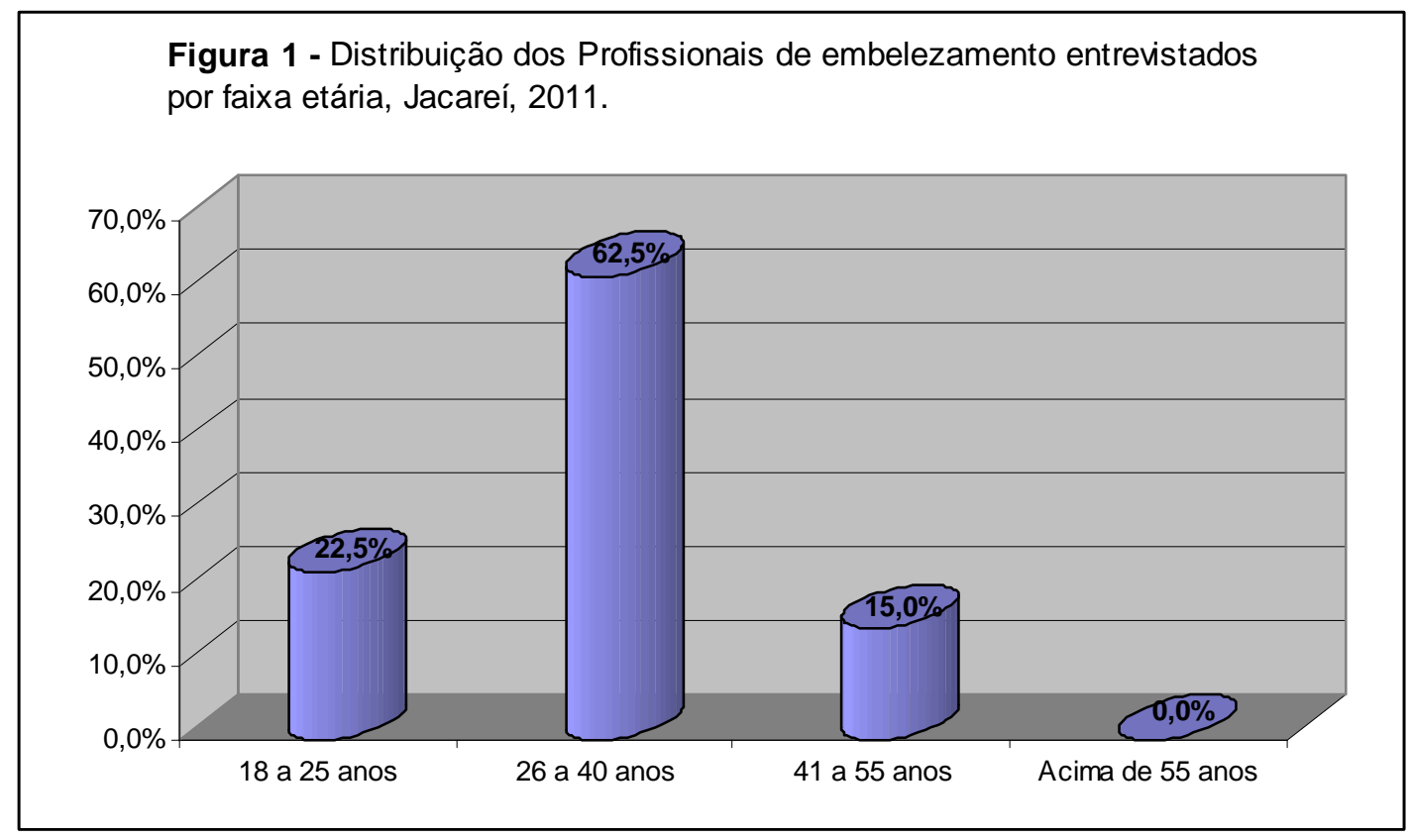

Do total, $70 \%$ dos profissionais concluíram o ensino médio, $15 \%$ possuíam o ensino fundamental completo, $5 \%$ ensino fundamental incompleto, $5 \%$ ensino médio incompleto, $2,5 \%$ superior incompleto, $2,5 \%$ o ensino superior completo e nenhum analfabeto. A Figura 2 apresenta a distribuição dos profissionais por escolaridade. 
Figura 2 - Distribuição dos profissionais de embelezamento entrevistados por escolaridade, Jacareí, 2011.

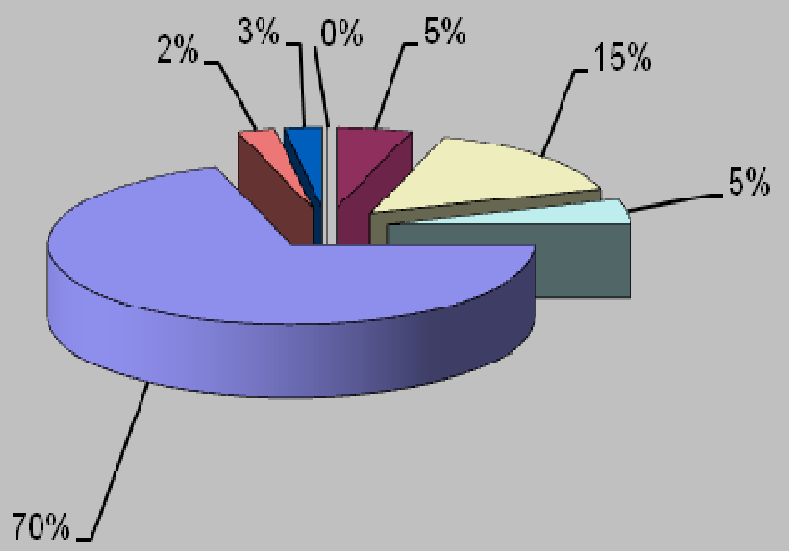

Quanto ao tempo de profissão, 37,5\% dos sujeitos de pesquisa, possuem mais de 10 anos de profissão, 20\% entre 6 e 10 anos, 17,5\% entre 3 a 5 anos, $10 \%$ entre 2 a 3 anos, 7,5\% entre 1 a 2 anos, 7,5\% menos de 1 ano.

Na Figura 3 os profissionais estão distribuídos por tempo de profissão. 


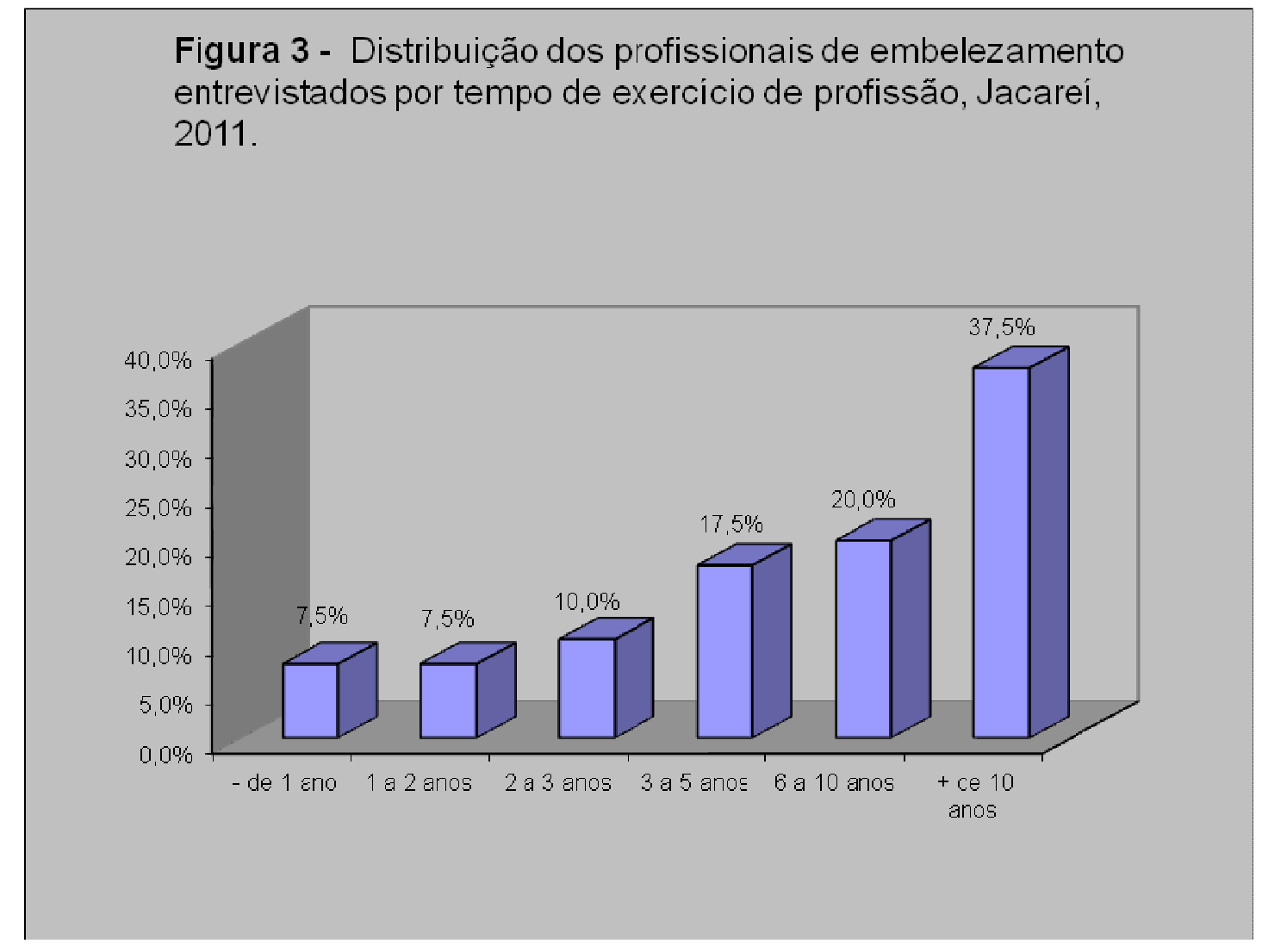

Este estudo constatou que a maioria dos profissionais de embelezamento são adultos jovens, possuem o ensino médio completo e trabalham na área há muito tempo, contudo estas características não garantem o cumprimento das boas práticas.

\subsection{CAPACITAÇÃO DOS PROFISSIONAIS ENTREVISTADOS}

Constatou-se que do total dos entrevistados (22) 55\% realizaram algum curso profissionalizante, de capacitação ou atualização para desenvolver a atividade. Dentre as 30 manicures e pedicures pesquisadas, 18 delas, ou seja, $45 \%$ do total de entrevistados realizaram algum tipo de curso profissionalizante ou capacitação. Porém, entre os tatuadores, piercers e maquiador definitivo, este 
número foi menor, apenas 04 deles, ou seja, $10 \%$ dos entrevistados realizaram algum tipo de curso.

Em que pese o fato de mais da metade dos profissionais afirmarem ter realizado curso de capacitação, a pesquisadora observou que, os procedimentos de biossegurança eram realizados erroneamente. Provavelmente, esses cursos são focados na técnica de embelezamento, não contemplando adequadamente o tema biossegurança. Tal fato pode ser devido à falta de regulamentação destas profissões no país e à inexistência de cursos de formação reconhecidos.

HELLARD et al. (2003), em estudo realizado com piercers na Austrália, observou que a formação desses profissionais era muito variada e, em alguns casos, insuficiente, pois também constatou por meio de sua observação que muitos não seguiam as boas práticas.

O Reino Unido também encontra dificuldade semelhante, visto que apesar da regulamentação exigir treinamentos adequados, não há nenhum curso de qualificação reconhecido (GRIFFITH e TENGNAH, 2005).

\subsection{PERCEPÇÃO DO RISCO DE TRANSMISSÃO DE DOENÇAS DURANTE O EXERCÍCIO PROFISSIONAL}

Em relação à percepção do risco de adquirirem doenças infecciosas durante suas atividades profissionais, $87,5 \%$ dos sujeitos acreditavam que poderiam adquiri-las e $12,5 \%$ que não, sendo que as doenças mais citadas passíveis de serem adquiridas foram AIDS, hepatite e micoses.

No entanto, quando a pergunta foi sobre a possibilidade de transmitir alguma doença para seu cliente durante o exercício profissional o resultado foi diferente, 57,5\% acreditavam que poderiam transmitir doenças, 40\% acreditavam que não e 2,5\% não souberam responder. As doenças que poderiam ser transmitidas foram as mesmas citadas anteriormente: AIDS, hepatite e micoses.

Noventa e cinco por cento dos entrevistados afirmaram saber o que é AIDS. 
Observou-se que os profissionais sabiam que a AIDS é uma doença transmissível e, quando solicitado que descrevessem a doença, muitos descreviam as formas de contágio e não a doença em si.

Quanto à hepatite, 55\% dos sujeitos afirmaram conhecê-la. No entanto, suas definições sobre a doença eram inseguras e incompletas.

Noventa e cinco por cento dos entrevistados afirmaram saber qual o modo de transmissão dessas doenças e, as associavam ao contato com sangue. Os modos de transmissão mais citados foram: relação sexual, transfusão de sangue e o compartilhar de agulhas. Dentre os sujeitos pesquisados, (8) 20\% deles sabiam que elas podem ser transmitidas por meio dos instrumentais. Contudo, foi observado que suas respostas eram mais direcionadas à transmissão da AIDS, não à hepatite.

HELLARD et al. (2003), em sua investigação sobre as práticas de controle de infecção e conhecimentos de hepatite $\mathrm{C}$ entre piercers na Austrália, verificou desconhecimento desses profissionais em relação à propagação do vírus da hepatite $\mathrm{C}(\mathrm{HCV})$.

Ainda, OLIVEIRA e FOCACCIA (2010), em sua pesquisa com manicures e pedicures da cidade de São Paulo, também encontraram um expressivo número de manicures e pedicures que desconhecia a forma de transmissão da hepatite $\mathrm{C}$ e hepatite B.

Também na Austrália, HEPWORTH e MURTAGH (2005), em seu estudo sobre segurança nos serviços de embelezamento e saúde dos trabalhadores, constataram que os entrevistados possuíam pouco conhecimento sobre transmissão de doenças infecciosas por meio de contato com sangue.

Não há dúvidas que a AIDS, comparada à hepatite, é uma doença com maior cobertura pela mídia e pelos programas oficiais. É necessária maior conscientização dos profissionais de embelezamento sobre transmissão e prevenção de doenças infecciosas.

Noventa e sete e meio por cento dos trabalhadores afirmaram saber como se prevenir para não adquirir AIDS e hepatite. As formas de prevenção mais citadas foram: o uso de camisinha, luvas, máscara, materiais descartáveis e por meio da esterilização dos materiais. 
Contudo, foi observado pela pesquisadora que somente $50 \%$ dos profissionais usavam luvas descartáveis, sendo que esta foi uma das formas de prevenção mais citadas por eles. Esse fato revela que o discurso dos entrevistados sobre procedimentos para controle de infecção era diferente do observado em suas práticas, assim como relatado por HELLARD et al. (2003) em sua investigação sobre as práticas de controle de infecção e conhecimentos de hepatite $\mathrm{C}$ entre piercers na Austrália.

ENGELMAN et al. (2010), em estudo com cirurgiões dentistas, revelaram que mesmo no meio de profissionais com formação universitária, nem todos observam as regras de biossegurança, apesar de estarem cientes da necessidade de aplicar os métodos estudados para o controle de infecção.

Embora os entrevistados possuíssem informações sobre os riscos á saúde presentes em suas atividades, suas ações não eram condizentes com este conhecimento. A percepção que dispunham sobre o risco de adquirirem doenças durante o exercício profissional não era suficiente para transformar suas ações. Esta realidade pode ser explicada por meio da má formação dos profissionais, pela deficiência na capacitação quanto à biossegurança, pelos custos envolvidos na prevenção de riscos ou até mesmo pela falha na fiscalização e orientação.

\subsection{EXPOSIÇÃO ACIDENTAL AO SANGUE}

Dentre os entrevistados, (18) $45 \%$ afirmaram ter tido contato com sangue de clientes sem estar usando luvas, demonstrando o quanto estão expostos aos agentes infecciosos. Os procedimentos mais comuns adotados por eles após o contato foi lavar as mãos e passar álcool. Além destas condutas, entre as manicures e pedicures também é frequente o costume de passar acetona nas mãos. Nenhum deles afirmou procurar serviço médico ou hospitalar após a exposição.

ISIHI (2010), em seu estudo com tatuadores e piercers na cidade de São Paulo, constatou que $73,23 \%$ deles tiveram contato direto com sangue de cliente, sendo que, somente 1,4\% procuraram serviço médico especializado ou hospital. 
OLIVEIRA e FOCACCIA (2010) relataram, em seu estudo sobre controle de infecção entre manicures e pedicures na cidade de São Paulo, que 54\% das profissionais afirmaram não tomar qualquer medida ao entrarem em contato com sangue de clientes.

O Guia de Orientações Técnicas sobre Hepatites B e C do Centro de Vigilância Epidemiológica do Estado de São Paulo informa que o risco médio de um indivíduo ser contaminado após exposição percutânea pode chegar a $60 \%$ no caso da hepatite B e entre $1 \%$ a $10 \%$ no caso da hepatite C (SÃO PAULO (ESTADO), 2002).

Os riscos de acidentes estão presentes nos serviços de embelezamento. Em caso de exposição percutânea ou permucosa ao sangue, a transmissão de doenças virais como AIDS e hepatite B podem ser inibidas por meio de ações profiláticas com a vacina e imunoglobulina, no caso da hepatite $B$, e antirretrovirais com diferentes composições e indicações, no caso da AIDS (OPERMAN e PIRES, 2003).

O presente trabalho aponta que os profissionais de embelezamento apresentam uma lacuna em seu conhecimento sobre normas de biossegurança, assim como observado por OBERDORFER et al. (2003a) em seu estudo sobre conhecimentos e atitudes em relação ao controle de infecção, com profissionais que realizam perfuração da pele em Sydney, Austrália.

\subsection{LAVAGEM DAS MÃOS}

Noventa e dois por cento dos profissionais afirmaram lavar as mãos entre todos os clientes, contudo, a quase inexistência de pia próximo ao local de atendimento sugere que este resultado não seja confiável.

ISIHI (2010) em sua pesquisa com tatuadores e perfuradores corporais no município de São Paulo, onde a totalidade dos pesquisados referiu lavar as mãos, também observou que um número significativo de sujeitos não lavava as mãos antes do procedimento e quase metade deles não possuíam no estúdio pia exclusiva para essa finalidade. 
A lavagem rotineira das mãos com água e sabão, elimina além de sujeiras, micro-organismos que se aderem à pele durante o desenvolvimento de atividades, mesmo com o uso de luvas. É a principal medida de bloqueio da transmissão de microorganismos (OPERMAN e PIRES, 2003).

\subsection{USO DE EQUIPAMENTOS DE PROTEÇÃO INDIVIDUAL}

No tocante ao uso de equipamentos de proteção individual constatou-se que (27) $67,5 \%$ dos entrevistados afirmaram usar equipamento de proteção individual e (13) 32,5\% afirmaram não usar nenhum tipo deles.

A Tabela 4 apresenta a adesão dos sujeitos de pesquisa aos equipamentos de proteção individual.

Tabela 4 - Adesão dos profissionais de embelezamento entrevistados aos equipamentos de proteção individual, Jacareí, 2011

\begin{tabular}{|l|l|}
\hline Tipo de equipamento de proteção individual & N/40
\end{tabular}

Luvas descartáveis

Máscara descartável

Luvas de borracha para limpeza dos instrumentais

Avental ou uniforme adequado
20

11

01

03
50

27,5

\section{2,5}

7,5

De maneira geral, todos os tatuadores, piercers e maquiador definitivo eram adeptos ao uso de algum tipo de equipamento de proteção, diferentemente das manicures e pedicures. Provavelmente, essa adesão é devido ao fato de 
ocorrerem, durante a tatuagem e perfuração da pele, sangramentos com frequência e intensidade maiores do que nos serviços de embelezamento de unhas.

Entre os sujeitos, que afirmaram usar algum tipo de equipamento de proteção individual, foram identificados os principais temas de suas falas e a quantidade de vezes que eles apareceram em suas respostas, justificando a adesão, conforme mostra o Quadro 1. O entrevistado pode apresentar mais de uma justificativa para a adesão aos equipamentos.

\begin{tabular}{|c|c|}
\hline \multicolumn{2}{|c|}{$\begin{array}{l}\text { Quadro } 1 \text { - Principais temas encontrados nas respostas dos sujeitr } \\
\text { de embelezamento sobre os motivos de usarem equipamentos de } \\
\text { vidual e o número de vezes que eles apareceram. Jacareí, } 2011 \text {. }\end{array}$} \\
\hline $\begin{array}{l}\text { Principais temas encontrados nas respostas dos } \\
\text { sujeitos sobre os motivos de usarem equipamen- } \\
\text { tos de proteção individual }\end{array}$ & $\begin{array}{l}\text { Número de vezes em que } 0 \\
\text { tema pareceu nas respostas } \\
\text { dos sujeitos }\end{array}$ \\
\hline Proteção do cliente e do profissional & 20 \\
\hline Higiene do serviço (marketing) & 07 \\
\hline Não sujar a roupa & 03 \\
\hline $\begin{array}{l}\text { Para não sentir o cheiro do pé, não respirar em } \\
\text { cima da pessoa }\end{array}$ & 01 \\
\hline Evitar contato com cliente & 02 \\
\hline
\end{tabular}

Dentre os profissionais que afirmaram usar equipamentos de proteção por higiene, estava a seguinte fala que foi literalmente transcrita: “...para o cliente ver que a profissional tem higiene". Por meio dela e outras relacionadas, a pesquisadora constatou que a motivação do profissional ao usar equipamentos de proteção era conquistar o cliente, fazer o marketing de seu trabalho, e não a prevenção de doenças e a proteção da saúde.

Foi observado pela pesquisadora que 06 manicures e pedicures que afirmaram usar luvas descartáveis para sua proteção, ou seja, 15\% dos 
entrevistados, contraditoriamente não as usavam, revelando novamente que seus discursos nem sempre coincidiam com suas práticas. Uma manicure se explicou por meio da fala: "a luva atrapalha", outra: "não acostumo com a luva". Essas falas foram transcritas literalmente.

Três manicures e pedicures, 7,5\% dos profissionais, afirmaram reutilizar luvas descartáveis. O Quadro 2 apresenta as falas das profissionais explicando e justificando o motivo de reutilizarem luvas descartáveis.

\begin{tabular}{|c|l|}
\hline \multicolumn{2}{|l|}{ Quadro 2 - Justificativa dos profissionais de embelezamento entrevistados que } \\
reutilizavam luvas descartáveis, Jacareí, 2011. \\
\hline Sujeitos & $\begin{array}{l}\text { Fala das manicures/pedicures justificando a reutilização de luvas } \\
\text { descartáveis }\end{array}$ \\
\hline 1 & "lavo a luva com sabão e penduro para secar no banheiro" \\
\hline 2 & "passo álcool na luva" \\
\hline 3 & "troco a luva quando ela fura" \\
\hline
\end{tabular}

O equipamento de proteção com maior adesão entre os entrevistados foram as luvas descartáveis. Apesar de ser o equipamento mais comum e acessível economicamente, apenas 50\% dos profissionais afirmaram usá-las, sendo que entre esses estavam ainda aqueles que de fato não as usavam e os que as reutilizavam, tornando a situação ainda mais preocupante.

Também JOHNSON et al. (2001), em seu estudo com manicures e pedicures, relataram que $35 \%$ desses profissionais afirmaram nunca usar luvas enquanto faziam as unhas de clientes e, muitos deles relataram estancar o sangramento das cutículas sem estar usando-as.

Uma dificuldade mencionada pelos tatuadores sobre equipamentos de proteção individual relaciona-se ao fato de precisarem apoiar seu braço sobre o corpo do cliente para obter firmeza ao tatuar. Contudo, quando o desenho a ser tatuado é grande ocupando uma longa extensão, o profissional entra em contato com áreas já tatuadas que apresentam sangramento. Para não ficarem com a pele 
do braço exposta ao contato direto com sangue é prática comum entre eles envolver os braços em filme plástico, idealizados para embalar alimentos, pois o avental é permeável e as luvas vão somente até o pulso. Segundo eles, não há disponível no mercado equipamento de proteção eficaz para esta parte do corpo.

No entanto, após pesquisa sobre o assunto, verificou-se que médicos veterinários durante seus procedimentos utilizam equipamento denominado luva de apalpação. Confeccionada de material impermeável, protege mão, braço e antebraço, chegando quase até o ombro. Esse equipamento poderia ser usado também para a proteção dos tatuadores.

\subsection{EQUIPAMENTOS USADOS PARA A ESTERILIZAÇÃO}

Observou-se que 7,5\% dos entrevistados dispunham de autoclave, 27,5\% de estufa, $57,5 \%$ de forninho, 2,5\% estufa e forninho, 2,5\% de autoclave e estufa, 2,5\% não realizavam esterilização.

A Tabela 5 foi elaborada com o tipo de equipamento usado para a esterilização e as quantidades encontradas nos serviços pesquisados.

\begin{tabular}{lll} 
Autoclave & 03 & 7,5 \\
Estufa & 11 & 27,5 \\
Forninho & 23 & 57,5 \\
Estufa e forninho & 01 & 2,5 \\
Autoclave e estufa & 01 & 2,5 \\
Não realizam esterilização & 01 & 2,5 \\
& & \\
\hline TOTAL & 40 & $100 \%$ \\
\hline
\end{tabular}


Dos 36 profissionais que dispunham de estufa e/ou forninho para a esterilização dos instrumentais, apenas (4) 11,1\% deles possuíam termômetro e termostato em seus aparelhos para a conferência da temperatura. Além disso, (14) $38,8 \%$ deles desconheciam a temperatura que seu aparelho atingia e/ou o tempo que ele permanecia ligado para realizar a esterilização, revelando a enorme falha na realização desse processo.

O "forninho", equipamento mais usado, não possuía termostato e/ou local para aferir a temperatura com termômetro. Sendo assim, pode-se afirmar que este equipamento não é adequado para a esterilização dos instrumentais.

A autoclave é o equipamento mais indicado para a esterilização. Vale ressaltar que, todas as autoclaves estavam em estúdios de tatuagem e piercing, além disso, apenas um desses estabelecimentos dispunha de "forninho". Nenhum dos serviços de manicure e pedicure dispunham de autoclave.

O maquiador definitivo foi o único profissional que afirmou não realizar esterilização, pois segundo ele, todos seus materiais eram descartáveis.

OBERDORFER et al. (2003b), por meio de estudo com serviços de embelezamento, constataram que os custos financeiros são uma barreira que dificultam a adesão às normas de biossegurança. Este fato pode explicar a grande ausência de equipamentos de esterilização adequados nos serviços pesquisados, visto que são de custo mais elevado que os frequentes forninhos.

$\mathrm{O}$ fato de serviços de manicure e pedicure serem bem mais baratos, se comparados aos serviços de tatuagem e piercing, pode explicar a ausência de autoclave em todos os estabelecimentos de embelezamento das mãos pesquisados. A inexistência de esterilizador adequado também pode ser devido à menor consciência dessas trabalhadoras em relação ao risco de exposição ao sangue quando comparadas aos tatuadores e piercers, visto que nos procedimentos de perfuração da pele ocorrem sangramentos sempre, diferentemente da retirada de cutículas, onde o sangramento é acidental e de pequeno volume. 


\subsubsection{Manutenção dos Equipamentos Usados na Esterilização}

Apenas 5\% dos sujeitos afirmaram realizar manutenção do aparelho esterilizador, contudo, nenhum deles apresentou registros, pois segundo eles, não estavam disponíveis no estabelecimento no momento da pesquisa.

ISIHI (2010) em seu estudo entre tatuadores e piercers na cidade de São Paulo também constatou falha dos profissionais na realização da manutenção preventiva e corretiva de seus equipamentos.

A manutenção preventiva deve ser realizada de acordo com recomendações do fabricante do equipamento, a corretiva sempre que necessário, ambas por pessoal qualificado e seus registros guardados (OPERMAN e PIRES, 2003).

\subsection{DESINFECÇÃO, LIMPEZA E ESTERILIZAÇÃO DOS} INSTRUMENTAIS

Apenas (9) 22,5\% dos pesquisados realizavam desinfecção prévia dos instrumentais por meio de imersão em solução apropriada. Os instrumentais usados eram colocados em caixa plástica lavável por apenas (6) 15\% dos entrevistados, sendo que apenas 5\% deles dispunham de sinalização como contaminados na caixa.

Dentre os 10 profissionais de tatuagem, piercing e maquiagem definitiva, (9) 90\% deles realizavam limpeza mecânica dos instrumentais com água, algum tipo de sabão e escova.

Já entre as manicures e pedicures, apenas uma delas afirmou não realizar limpeza mecânica. No entanto, a pesquisadora por meio de sua observação, verificou que as profissionais que afirmaram realizá-la, consideravam limpeza mecânica apenas a limpeza dos alicates com a mão para retirar os resíduos de cutículas ou no máximo passar neles algodão embebido em álcool ou acetona.

Noventa e dois e meio por cento dos sujeitos de pesquisa afirmaram saber o que é a esterilização de instrumentais e descreveram o processo. Três 
manicures e pedicures, $7,5 \%$ do total, afirmaram desconhecer e não descreveram esterilização.

As temperaturas usadas pelos profissionais para a esterilização variavam entre $90^{\circ} \mathrm{C}$ e $300^{\circ} \mathrm{C}$ e, o tempo gasto para sua realização oscilou de 20 minutos até $12 \mathrm{~h}$. Ainda sobre o tempo gasto para a esterilização uma manicure afirmou: "o dia inteiro", outra: "de um dia para o outro".

Onze manicures e pedicures, ou seja, $27 \%$ dos entrevistados, não sabiam qual temperatura seu forninho atingia. Quinze por cento dos entrevistados não sabiam por quanto tempo os instrumentais permaneciam no forninho, pois, depois de ligado, ele desligava sozinho.

Por meio das respostas dos entrevistados a pesquisadora observou que eles tinham consciência da necessidade de higienizar os materiais e de submetêlos ao calor por determinado tempo. Entretanto, o uso de tempo e temperatura diferentes do preconizado evidenciou o desconhecimento sobre o assunto e os erros na esterilização.

OLIVEIRA e FOCACCIA (2010), também encontraram práticas errôneas referentes à biossegurança, sendo que somente $7,14 \%$ das manicures e pedicures entrevistadas conheciam o tempo e a temperatura apropriados para a esterilização.

Vale lembrar que para garantir a esterilização, a temperatura utilizada deve ser de $170^{\circ} \mathrm{C}$ por uma hora ou $160^{\circ} \mathrm{C}$ por duas horas (ANVISA, 2000; MINISTÉRIO DA SAÚDE. SECRETARIA DE ASSISTÊNCIA À SAÚDE. 1994; MINISTÉRIO DA SAÚDE. SECRETARIA DE POLÍTICAS DE SAÚDE. 2000; SÃO PAULO (ESTADO), 1995).

Constatou-se também que dentre os 36 sujeitos que dispunham de estufa e/ou forninho, 14 deles, ou seja, 38,8\% desse grupo afirmaram abrir o equipamento durante o processo de esterilização e, quando isso acontecia somente 08 deles, ou seja, 22,2\% desse grupo afirmaram reiniciar o processo. NARESSI et al. (2004) em seu estudo com cirurgiões dentistas também fazem referência a uma alta porcentagem de profissionais que interrompiam o ciclo de esterilização da estufa.

Se a estufa for aberta antes do término do tempo preconizado, há uma quebra no ciclo de esterilização devido à diminuição da temperatura interna do aparelho. É necessário iniciar novamente o ciclo, aguardando que o equipamento 
atinja a temperatura ideal e, a partir daí, realizar uma nova contagem do tempo recomendado, sem outras interrupções.

Constatou-se que dentre os 09 profissionais de tatuagem, piercing pesquisados, 03 deles, afirmaram utilizar materiais não estéreis para perfurar a pele. Segundo eles, a "jóia" que perfura a pele não pode ser esterilizada devido a suas características químicas.

A maquiadora definitiva afirmou usar agulha estéril e descartável para a realização de seu trabalho.

Além de tudo isso, 95\% dos sujeitos de pesquisa não possuíam rotinas e instruções escritas para a realização dessas atividades, o que pode ser um fator agravante dessa precária situação.

Este estudo evidencia a necessidade de orientá-los quanto à maneira correta de realizar a desinfecção, limpeza e esterilização e à importância de todas as etapas do processo. Portanto, devem ser ofertados a esses profissionais treinamentos com qualidade sobre boas práticas e biossegurança.

\subsubsection{Controle em Processo de Esterilização}

Somente 5\% dos trabalhadores afirmaram realizar controle biológico do processo de esterilização, no entanto nenhum deles apresentou registros.

É importante salientar que a Resolução SS-374 dispõe sobre a necessidade de avaliar a eficácia do método de esterilização adotado, por meio do uso de indicadores, com frequência no mínimo semanal (SÃO PAULO (ESTADO), 1996). O uso de indicadores de esterilização para o monitoramento do processo é importante para comprovar a validade do processo.

NARESSI et al. (2004), em sua análise das formas de esterilização e do meio de controle empregados pelos cirurgiões dentistas de São José dos Campos, também constataram que a maioria dos entrevistados não utilizavam nenhum tipo de indicador de esterilização. 


\subsection{ACONDICIONAMENTO E ARMAZENAMENTO DE} MATERIAIS ESTÉREIS

Somente vinte por cento dos sujeitos utilizavam invólucros para embalar os instrumentais, porém, as caixas e embalagens não eram identificadas com data da esterilização e prazo de validade. Eles afirmaram abrir a embalagem e/ou caixa onde os materiais estéreis estavam acondicionados somente no momento do uso.

Os instrumentais esterilizados eram acondicionados e armazenados de forma a garantir a manutenção da esterilização por apenas 12,5\% dos trabalhadores, os demais os deixavam, não acondicionados, dentro da própria estufa, sobre prateleiras ou em gavetas inapropriadas.

Contraditoriamente, SILVA et al., (2007) constataram entre tatuadores e piercers no Recife que todos os sujeitos armazenavam seus materiais estéreis de forma adequada e em local específico para esse fim. A intenção ao embalar e armazenar os artigos estéreis adequadamente é que sua esterilidade seja mantida até serem usados.

\subsection{MATERIAIS DE USO ÚNICO}

Quanto aos materiais de uso único, 17 manicures e pedicures, ou seja, $42,5 \%$ do total de pesquisados afirmaram reutilizar lixa e/ou palito. Algumas manicures e pedicures usavam o palito de metal, que pode ser esterilizado, porém esses não foram contabilizados nesse estudo.

Existe outra modalidade que ainda não é tão comum, onde cada cliente tem o seu próprio kit de materiais, que, ou o deixa no salão ou o leva consigo não compartilhando com outros. Os casos dessa nova modalidade também não foram contabilizados nesse estudo.

Constatou-se por meio do relato de 03 manicures e pedicures, ou seja, $7,5 \%$ dos entrevistados, o costume de colocar o palito de madeira no 
esterilizador. Ainda, observou-se o hábito de limpá-lo com álcool e reutilizá-lo. A madeira é um material poroso e não há indicação para sua esterilização.

Cinco manicures, $12,5 \%$ dos profissionais, afirmaram descartar o material somente quando eles entravam em contato com sangue ou com unha que apresentassem micose ou infecção.

Entre os tatuadores e piercers, $100 \%$ afirmaram descartar a lâmina após depilar o cliente, porém 03 tatuadores, 7,5\% dos sujeitos, afirmaram usar também a "máquina de barbeiro", onde a lâmina utilizada não é descartável.

A frequente prática de reutilização de materiais de uso único, verificada durante a pesquisa, pode ser um meio de transmissão de doenças e, a principal preocupação é que um corte causado por um material reutilizado transmita infecções.

JOHNSON et al. (2001), em seu estudo com manicures e pedicures no Canadá, constatou que $95 \%$ a $100 \%$ dos materiais descartáveis eram reutilizados, mesmo não sendo recomendação do fabricante.

Também OLIVEIRA e FOCACCIA (2010), em seu estudo com manicures e pedicures na cidade de São Paulo, constataram que $93 \%$ das entrevistadas reutilizavam materiais de uso único.

Portanto, trabalhadores dos serviços de embelezamento precisam conhecer os riscos presentes na reutilização de materiais descartáveis. Para isso é necessária maior divulgação dos riscos inerentes a essas práticas, quer seja por meio de campanhas de saúde e orientações sobre transmissão de doenças infecciosas direcionadas aos profissionais de embelezamento, ações da Vigilância Sanitária local como fiscalizações e orientações, ou ainda, por exigência de capacitação em biossegurança para o exercício profissional.

\subsection{ESTRUTURA FÍSICA DOS SERVIÇOS PESQUISADOS}

O Quadro 3 apresenta os resultados dos itens relacionados à estrutura física observados nos serviços de embelezamento. 


\begin{tabular}{|l|l|l|}
\hline Quadro 3 - Estrutura física dos serviços de embelezamento pesquisados, Jacareí, 2011. & N/40 & $\%$ \\
\hline Estrutura física dos serviços de embelezamento & 03 & 7,5 \\
\hline $\begin{array}{l}\text { Existência de pia para higienização das mãos dos } \\
\text { profissionais próxima ao local de atendimento ao cliente }\end{array}$ & 12 & 30 \\
\hline $\begin{array}{l}\text { Existência de sabão líquido e toalha descartável para a } \\
\text { higienização das mãos dos profissionais }\end{array}$ & 13 & 32,5 \\
\hline $\begin{array}{l}\text { Existência de álcool gel para a higienização das mãos dos } \\
\text { Profissionais }\end{array}$ & 01 & 2,5 \\
\hline $\begin{array}{l}\text { Existência de área dotada de pia exclusiva para a limpeza } \\
\text { dos instrumentais }\end{array}$ & 04 & 10 \\
\hline $\begin{array}{l}\text { Existência de área específica para a esterilização dos } \\
\text { Instrumentais }\end{array}$ & 37 & 92,5 \\
\hline $\begin{array}{l}\text { Piso e parede de material liso, lavável, impermeável e de } \\
\text { fácil limpeza. }\end{array}$ & 04 \\
\hline
\end{tabular}

Verificou-se que somente $7,5 \%$ dos profissionais dispunham de pia para a lavagem das mãos próxima ao atendimento ao cliente. Os demais afirmaram usar alguma outra como a pia do banheiro ou o lavatório de cabelos.

Apesar de $30 \%$ possuírem sabão líquido e papel-toalha em seu estabelecimento, quase a totalidade desses acessórios estava distante do local de trabalho, como na pia do banheiro. Alguns dispositivos de papel-toalha estavam vazios no momento da visita sendo utilizada a toalha de tecido. O mais comum foi encontrar sabonete em barra e toalha de pano, ou ainda a ausência deles.

Toalhas de tecido não são indicadas, pois permanecem úmidas, favorecendo a propagação bacteriana (ANVISA, 2007c).

Trinta e dois e meio por cento dos entrevistados dispunham de álcool em gel para higienização das mãos, 5\% dispunham de álcool líquido. É fato que quando usado adequadamente o álcool etílico $70 \%$ apresenta excelente ação germicida, porém não dispensa a necessidade da correta lavagem e secagem das mãos.

Constatou-se a ausência de área específica para limpeza e esterilização de instrumentais, assim como de pia exclusiva para sua lavagem. Os instrumentais eram lavados na pia do banheiro, no tanque, no lavatório de cabelos, na pia para 
preparar produtos, tintas e para a lavagem de outros artigos como louças usadas na alimentação. WEBER (2001), em seu estudo com piercers nos Estados Unidos, destaca a necessidade de área dedicada para a realização dessas atividades.

Também a ANVISA, por meio do material de referência para estados e municípios elaborarem e instituírem legislações locais, recomenda que o ambiente destinado ao processamento de artigos deverá dispor de pia com bancada para o preparo, desinfecção ou esterilização de materiais. Sugere que caso não exista sala para processamento de material, esta atividade pode estar localizada em uma área dentro da sala de procedimentos, desde que estabelecida barreira técnica (ANVISA, 2009).

Noventa e dois e meio por cento dos serviços pesquisados apresentava a tríade "piso, parede e teto" em condições satisfatórias, sendo que a RDC 50 exige que eles sejam de materiais liso, lavável e impermeável (ANVISA, 2002). Quanto à estrutura física, não foram observadas diferenças entre os cadastrados e os não cadastrados junto à Vigilância Sanitária.

\subsection{MATERIAIS ESTÉREIS}

Nenhum dos entrevistados controlava a validade dos materiais estéreis. Também, não controlavam a validade dos instrumentais esterilizados, sequer registravam a data em que a esterilização foi realizada.

O prazo de validade dos instrumentais esterilizados é bastante variável e depende do tipo de invólucro, da eficiência do empacotamento, do local de estocagem quanto à umidade e, se são prateleiras abertas ou fechadas, o que indicará a circulação de poeira (OPERMAN e PIRES, 2003).

Para papel kraft, estabeleceu-se a rotina de 07 dias de estocagem e para tecido, 15 dias. Para papel crepado, 02 meses em armário fechado. Para papel grau cirúrgico ou polietileno 06 meses em armário fechado (OPERMAN e PIRES, 2003). 


\subsection{ACONDICIONAMENTO E DESCARTE DE RESÍDUOS}

Dentre os 10 profissionais de tatuagem, piercing e maquiagem definitiva entrevistados, (7) 70\% deles dispunham de recipiente rígido resistente à punção para o descarte de agulhas e objetos.

Somente (14) $35 \%$ do total de serviços pesquisados dispunham de lixeira com tampa e pedal para o descarte de resíduos como luvas de procedimento, algodão e etc.

Todos os sujeitos afirmaram que o lixo comum gerado no serviço era coletado por empresa de limpeza urbana.

Dentre os serviços pesquisados, apenas os serviços de tatuagem, piercing e maquiagem definitiva geravam lixo infectante e necessitavam de coleta especial para o mesmo.

Dentre o grupo de tatuadores, piercers e maquiador definitivo entrevistados, apenas $60 \%$ afirmaram dispor de coleta especial. O maquiador definitivo não dispunha de coleta especial para o lixo infectante gerado em seu estabelecimento e afirmou encaminhá-lo para o consultório de uma amiga dentista, que daria o destino correto. Um tatuador afirmou encaminhá-lo para outro estúdio de tatuagem que possuiria coleta especial, outro afirmou embalar e levá-lo para uma farmácia próxima, e ainda, outro possuía um desintegrador de agulhas onde elas eram trituradas e seus restos descartados no lixo comum.

Os resíduos infectantes gerados nos serviços de embelezamento são problema para a saúde pública, pois representam risco à saúde e ao ambiente.

Jacareí dispõe de coleta especial para o lixo infectante. Para que os estabelecimentos tenham acesso a esse serviço, é necessário o cadastramento junto ao setor responsável da prefeitura do município. Para o cadastro, o interessado deve apresentar documento de identificação do profissional responsável, do estabelecimento e comprovante de recolhimento do "imposto sobre serviços". A apresentação da licença da Vigilância Sanitária não é solicitada para a efetivação do cadastro. 
Após a efetivação desse cadastro, a coleta do lixo infectante em serviços de embelezamento é realizada semanalmente.

Portanto, pode-se concluir que os serviços que não possuem coleta especial para seu lixo infectante provavelmente não são cadastrados se quer junto ao setor de meio ambiente, que é o responsável pela coleta, e/ou não contribuem com o "Imposto sobre serviços". Esses serviços devem implantar o gerenciamento de resíduos.

\subsection{LIMPEZA DO AMBIENTE}

Todos os entrevistados afirmaram realizar a limpeza do ambiente e dos mobiliários diariamente. A importância dessa limpeza consiste também na possibilidade de pequenas porções de sangue caírem em macas ou cadeiras onde o cliente está acomodado. Apesar de objetos e ambiente não serem fontes comuns de contaminação, podem estar envolvidos em surtos de infecções. O vírus da hepatite B é estável e resistente, podendo resistir no meio ambiente até uma semana. Considerando esta estabilidade, a transmissão indireta pode ocorrer através do contato humano com superfícies ou objetos inanimados (ARAÚJO, 2008).

\subsection{NÚMERO DE INSTRUMENTAIS EXISTENTES NOS SERVIÇOS DE EMBELEZAMENTO}

Dentre as 30 manicures e pedicures entrevistadas, (20) 66,6\% delas possuíam alicates em quantidade suficiente de forma a garantir a esterilização deles a cada uso. De modo geral, as manicures e pedicures não possuíam espátulas para afastar a cutícula em número suficiente, além do fato de muitas delas possuírem cabo de plástico e não poderem ser submetidas a altas temperaturas para a esterilização. 
A Portaria CVS 11 de 1993, que normatiza o funcionamento dos estabelecimentos que exercem atividade de podólogo, preconiza a existência de no mínimo 06 unidades de cada instrumental utilizado no serviço de podologia (SÃO PAULO (ESTADO), 1993). No entanto, não existe padronização de número mínimo de instrumentais necessários para as atividades de embelezamento, além disso, o número de instrumentais necessários pode variar de acordo com a demanda do estabelecimento.

Vale lembrar que é necessário bem mais de uma hora para a realização da desinfecção, limpeza e esterilização do instrumental usado, daí a necessidade da existência de outros instrumentais já esterilizados para a continuidade do atendimento.

JHONSON et al. (2001), em seu estudo com manicures no Canadá, constataram situações em que os profissionais não possuíam tempo suficiente para realizar a desinfecção de seus instrumentais entre o atendimento de um cliente e outro. Esse mesmo estudo constatou que a maioria dos serviços de manicure e pedicure pesquisados apresentavam riscos de transmissão de doenças infecciosas.

Esses instrumentais são de baixo custo, não justificando a ausência da quantidade preconizada.

$\mathrm{Na}$ modalidade ainda pouco comum, onde cada cliente tem o seu próprio kit de materiais, incluindo alicates e espátulas, não há o compartilhamento dos mesmos entre clientes, minimizando o risco. Porém, considerando que eles não passam por limpeza e esterilização, ainda existe o risco da transmissão de doenças entre clientes e profissionais. 


\section{NORMATIZAÇÕES QUE REGULAMENTAM OS SERVIÇOS DE EMBELEZAMENTO}

Outro aspecto importante é a legislação que regulamenta o setor. $O$ município de Jacareí adota o Código Sanitário do Estado de São Paulo (SÃO PAULO (ESTADO), 1998) e, utiliza para as inspeções nos serviços de manicure e pedicure o Roteiro de Inspeção em Salões de Beleza da Resolução SS-196 de 1998 (S ÃO PAULO (ESTADO), 1998).

Esse Roteiro não fornece aos trabalhadores instruções para a realização de procedimentos adequados, limitando-se à verificação da estrutura fisicofuncional, que apesar de importante, não é suficiente para garantir o cumprimento das boas práticas.

Boas práticas podem ser definidas como um conjunto de normas que estabelecem e padronizam procedimentos e conceitos de boa qualidade para processos, serviços e produtos, visando atender aos padrões mínimos estabelecidos por órgãos reguladores, cuja incumbência é zelar pelo bem estar da comunidade (PEREIRA FILHO e BARROCO, 2004).

Sendo assim, para a prevenção de infecções é necessário disponibilizar a estes profissionais normas claras e orientações detalhadas sobre boas práticas para o segmento.

RAYMOND et al. (2001), em seu estudo sobe controle de infecção entre tatuadores de Minneapolis e Saint Paul, referem que em regiões onde existe regulamentação sobre biossegurança nos serviços de embelezamento, os profissionais que nelas atuam realizam melhor controle de infecção do que em locais onde não há normatização.

No entanto, ao comparar o Roteiro de Inspeção em Salões de Beleza da Resolução SS-196 de 1998 (SÃO PAULO (ESTADO),1998) com a Portaria CVS 11 de 1993, que dispõe sobre serviços de podólogo (SÃO PAULO (ESTADO), 1993), fica evidente a necessidade de uma normatização mais específica para os serviços de manicure e pedicure. Diferentemente do Roteiro de Inspeção em Salões de Beleza, a Portaria CVS 11 de 1993 preconiza a lavagem e desinfecção dos instrumentais, uso de estufa como equipamento esterilizador, tempo e 
temperatura ideal para a esterilização, além do número mínimo de instrumentais (SÃO PAULO (ESTADO), 1993).

Estudos realizados por JHONSON et al. (2001) com manicures e pedicures e por WORP et al. (2006) com tatuadores, piercers e profissionais de maquiagem definitiva também concluíram que é preciso desenvolver protocolos para o controle de infecções nesses serviços.

Já os serviços de tatuagem e piercing dispõem de legislação mais específica, a Portaria CVS 12 de 1999 (SÃO PAULO (ESTADO), 1999). Essa Portaria preconiza que gabinetes de tatuagem e piercing só poderão funcionar mediante cadastramento junto à autoridade sanitária competente. Preconiza também que estes estabelecimentos devem dispor de registros de clientes, livro para anotação de acidentes e reações alérgicas e, garantir a prestação de informações a todos os clientes sobre os riscos decorrentes da execução desses procedimentos. Normatiza também a estrutura física dos estabelecimentos, procedimentos como a lavagem das mãos e o uso de luvas descartáveis. Dispõe sobre a obrigatoriedade da realização de descontaminação, limpeza e esterilização dos instrumentos e materiais. Dispõe ainda sobre a não reutilização de materiais de uso único, o acondicionamento e descarte de resíduos e sobre o acondicionamento de produtos e materiais descartáveis.

Contudo, ela também apresenta lacunas e, não contempla instruções para a realização da descontaminação, limpeza, esterilização de materiais e nem sobre o controle em processo. Além do mais, a Portaria CVS 12 de 1999 não considera um aspecto muito importante, a capacitação profissional (SÃO PAULO (ESTADO), 1999).

Diferentemente, nos Estados Unidos da América, o Estado de Oregon possui normatização abrangente que contempla a formação dos tatuadores e piercers, incluindo a educação continuada obrigatória e a aplicação de um exame escrito. Outros estados americanos definiram currículo e número de horas necessárias para a formação profissional (ARMSTRONG, 2005).

De modo geral, nos últimos anos a Agência Nacional de Vigilância Sanitária tem regulamentado outros setores de forma clara, não se restringindo a parâmetros estruturais. As orientações vão desde estrutura física, recursos 
humanos, procedimentos, materiais, equipamentos até a garantia da qualidade, como observado na Resolução RDC 67 de 2007, que trata sobre as boas práticas de manipulação de farmácias (ANVISA, 2007b). Algumas normatizações até estabelecem indicadores que devem ser monitorados pelos serviços e disponibilizados para as autoridades sanitárias, como na Resolução RDC 52 de 2011 que dispõe, entre outras coisas, sobre o controle de medicamentos que contenham a substância sibutramina (ANVISA, 2011).

No entanto, não há regulamentação federal que contemple os serviços de embelezamento.

Vale ressaltar que a posição atual da Agência Nacional de Vigilância Sanitária, ANVISA, é enfatizar suas ações nas atividades de alta complexidade deixando aos Estados e Municípios a responsabilidade da fiscalização e regulamentação complementar dos serviços de baixa complexidade, nos quais se enquadram os serviços de embelezamento.

A ANVISA disponibilizou referência técnica para o funcionamento dos serviços de estética e embelezamento sem responsabilidade médica (ANVISA, 2009), porém este material não tem qualquer valor legal, sendo apenas material de referência para que estados e municípios elaborem e instituam legislações locais, entretanto, a maioria dos municípios, incluindo Jacareí, não normatizaram a prestação destes serviços.

Considerando as dificuldades enfrentadas pelas Vigilâncias Municipais como a escassez e a desqualificação profissional, caberia a ANVISA e aos Estados, os quais possuem equipe multiprofissional qualificada e estruturada se comparados aos municípios, a normatização desses serviços.

Na Austrália, em 1999 e em 2001, foram desenvolvidos guias com orientações sobre boas práticas de perfuração corporal para tatuadores e piercers. Estes guias traziam instruções e descreviam processos como limpeza, desinfecção e esterilização. Posteriormente, realizou-se um estudo para avaliar a eficácia das práticas de controle de infecção após a distribuição dos guias. O estudo constatou que a maioria dos profissionais de tatuagem e piercing receberam estes guias durante as inspeções realizadas pelos oficias de saúde (OBERDORFER et al., 2003a). 
Muitos países como a Austrália, têm desenvolvido regulamentos visando o controle de infecção e prevenção de doenças relacionadas aos serviços de embelezamento (OBERDORFER et al., 2003a).

Na Itália, um decreto de 2004 impõe aos profissionais de arte corporal protocolos de higiene, capacitação e educação em saúde, e também o monitoramento dos estúdios (ARMSTRONG et al., 2007).

Em Amsterdã, Holanda, a regulamentação sanitária para os serviços de tatuagem, piercing e maquiagem definitiva está em vigor desde 1987, porém estas diretrizes são atualizadas regularmente, devido às frequentes mudanças nas técnicas e materiais envolvidos (WORP et al., 2006).

\section{DISCUSSÃO GERAL}

Os profissionais de embelezamento não são capacitados quanto à biossegurança, sendo que sua percepção sobre o risco de transmissão de doenças infecciosas durante a prática profissional é insuficiente para a adesão às normas de precaução padrão.

Estão expostos ao sangue de clientes, sendo poucos os adeptos ao uso de equipamentos de proteção individual.

A partir desta premissa pode-se deduzir que o risco de transmissão de doenças pode ser maior nas práticas desses profissionais ambulantes, pois vão de casa em casa carregando seu material. É improvável que levem consigo instrumentais suficientes para a troca a cada cliente ou que carreguem esterilizador e até mesmo que permaneçam na mesma residência o tempo necessário para completar o ciclo da esterilização, não possuindo, portanto, condições de realizar a limpeza, desinfecção e esterilização de seus instrumentais.

Também são grandes as chances daqueles que atendem em seu próprio domicílio não possuírem instalações adequadas, mas um ambiente de trabalho improvisado. 
A realidade da prestação de serviços de embelezamento por esses profissionais pode ser ainda pior do que a observada.

Em janeiro de 2012, foi promulgada a Lei 12592 reconhecendo as profissões de manicure, pedicure, cabeleireiro, barbeiro, esteticista, manicure, pedicure, depilador e maquiador (BRASIL, 2012). Entretanto, os tatuadores, piercers e profissionais de maquiagem definitiva não foram incluídos, sendo que os procedimentos realizados por eles representam risco ainda maior à saúde de clientes e profissionais, pois a exposição ao sangue está presente em todos os seus procedimentos.

Essa legislação dispõe de forma muito sucinta e em pouquíssimas palavras sobre a obrigatoriedade dos profissionais em obedecer às normas sanitárias e realizar a esterilização de seus instrumentais, além disso, não contempla um aspecto muito importante, a formação desses profissionais.

É imprescindível, além de reconhecer e regulamentar essas profissões, regulamentar também a formação dos profissionais, exigindo capacitação em biossegurança para o desempenho das atividades, pois, somente por meio da prestação de serviços devidamente normatizados, realizados por profissionais capacitados e de forma harmônica às regulamentações, a saúde de trabalhadores e usuários pode ser protegida.

Portanto, considerando todos os aspectos observados e discutidos neste trabalho, novamente reforçamos a necessidade da disponibilização de normas sanitárias claras e pormenorizadas, que contemplem todos os processos de trabalho envolvidos.

\section{CONCLUSÕES}

Os resultados obtidos permitem concluir que:

1) As condições sanitárias e de biossegurança nos serviços de embelezamento são bastante precárias, expondo a saúde de clientes e profissionais. 
2) Os profissionais não estão capacitados adequadamente no quesito biossegurança, apesar de terem realizado cursos e treinamentos.

3) Os entrevistados possuem noção do risco de transmissão de doenças infecciosas durante a realização de suas atividades, no entanto, suas práticas revelam que esse conhecimento é insuficiente para efetivar o cumprimento das medidas de precaução padrão.

4) A estrutura fisicofuncional dos serviços pesquisados é insatisfatória.

5) $\mathrm{O}$ processo de esterilização dos instrumentais, realizado pelos profissionais de embelezamento, é falho e incompleto.

\section{RECOMENDAÇÕES}

Os resultados e conclusões evidenciados no presente estudo permitem-nos oferecer as seguintes recomendações:

1) Realização de campanha de esclarecimento aos profissionais de embelezamento, por meio de mídia escrita, palestras, treinamento de profissionais visando o conhecimento sobre transmissão e prevenção de doenças infecciosas e de cuidados fundamentais de biossegurança.

2) Disponibilização de normas e/ou protocolos voltados aos serviços de manicure, pedicure, tatuagem, piercing e maquiagem definitiva que não se restrinjam à estrutura, mas que contemplem todos os processos de trabalho relacionados aos serviços de embelezamento.

3) Intensificação da busca ativa, pela Vigilância Sanitária, dos serviços de embelezamento, cadastrando, fiscalizando e orientando frequentemente esses serviços.

4) Orientação aos gestores dos cursos de formação dos profissionais de manicure, pedicure, tatuagem, piercing e maquiagem definitiva, sobre a relevância do tema biossegurança em sua grade curricular.

5) Regulamentação dessas profissões e obrigatoriedade de cursos de formação reconhecidos para exercê-las. 


\section{REFERÊNCIAS}

Agência Nacional de Vigilância Sanitária. Curso básico de controle de infecção hospitalar. Caderno C: métodos de proteção anti-infecciosa. Brasília, DF; 2000 [acesso jan 2012]. Disponível em: http://www.cvs.saude.sp.gov.br/pdf/CIHCadernoC.pdf

Agência Nacional de Vigilância Sanitária. Resolução da Diretoria Colegiada - RDC $\mathrm{n}^{\circ}$ 50, de 21 de fevereiro de 2002. Dispõe sobre o Regulamento Técnico para planejamento, programação, elaboração e avaliação de projetos físicos de estabelecimentos assistenciais de saúde. Diário Oficial da União. 20 mar 2002; Seção $1: 39$.

Agência Nacional de Vigilância Sanitária. Higienização das Mãos em Serviços de Saúde. Brasília, DF; 2007a [acesso 13 jan 2012]. Disponível em: http://www.anvisa.gov.br/hotsite/higienizacao_maos/manual_integra.pdf

Agência Nacional de Vigilância Sanitária. Resolução da Diretoria Colegiada - RDC $n^{\circ}$ 67, de 08 de outubro de 2007. Dispõe sobre Boas Práticas de Manipulação de Preparações Magistrais e Oficinais para Uso Humano em farmácias. Brasília, DF; 2007 b [acesso 04 jub 2012]. Disponível em: http://189.28.128.100/dab/docs/legislacao/resolucao67_08_10_07.pdf

Agência Nacional de Vigilância Sanitária. Segurança do paciente - Higienização das mãos. Brasília, DF; 2007c [acesso 13 jan 2012]. Disponível em: http://www.anvisa.gov.br/servicosaude/manuais/paciente_hig_maos.pdf

Agência Nacional de Vigilância Sanitária. Referência técnica para o funcionamento dos serviços de estética e embelezamento sem responsabilidade médica. Brasília, DF; 2009. [acesso 07 fev 2012]. Disponível em: http://portal.anvisa.gov.br/wps/wcm/connect/527126804745890192e5d63fbc4c6735/ 
$\underline{\text { Servicos }+ \text { de+Estetica+e+Congeneres.pdf?MOD=AJP }}$

ERES\&useDefaultText $=0 \&$ useDefaultDesc $=0$

Agência Nacional de Vigilância Sanitária. Resolução da Diretoria Colegiada - RDC $n^{\circ}$ 52, de 06 de outubro de 2011. Dispõe sobre a proibição do uso das substâncias anfepramona, femproporex e mazindol, seus sais e isômeros, bem como intermediários e medidas de controle da prescrição e dispensação de medicamentos que contenham a substância sibutramina, seus sais e isômeros, bem como intermediários e dá outras providências. Disponível em: http://www.anvisa.gov.br/hotsite/anorexigenos/pdf/RDC\%20522011\%20DOU\%2010\%20de\%20outubro\%20de\%202011.pdf

Armstrong ML. Tattooing, Body Piercing, and Permanent Cosmetics: A historical and current view of state regulations, with continuing concerns. J Environ Health. 2005;67(8):38-43.

Armstrong ML, Koch JR, Saunders JC, Roberts AE, Owen DC. The hole picture: risks, decision making, purpose, regulations, and the future of body piercing. Clin Dermatol. 2007;25:398-406.

Associação Brasileira da Indústria de Higiene Pessoal, Perfumaria e Cosméticos. [homepage na internet]. Dados do mercado. Panorama do setor. Mercado Brasileiro [acesso em: 18 de jan de 2012]. Disponível em:

http://www.abihpec.org.br/wp-content/uploads/2010/11/Microsoft-WordPanorama-do-setor-2010-2011-14_04_2011.pdf

Associação Paulista de Estudos e Controle de infecção Hospitalar. Esterilização de artigos em unidades de saúde. $2^{\text {a }}$ ed. São Paulo: APECIH; 2003.

Brasil. Lei $n^{\circ}$ 8080, de 19 de setembro de 1990. Dispõe sobre as condições para a promoção, proteção e recuperação da saúde, a organização e o funcionamento 
dos serviços correspondentes e dá outras providências. Diário Oficial da União. 20 set 1990; Seção 1:018055.

Araújo ESA, organizador. O ABC das hepatites: manual clínico para manuseio, terapia e prevenção da hepatite B. São Paulo: Bristol-Meyers-Squibb; 2008.

Brasil. Lei $\mathrm{n}^{\circ} 12592$ de 18 de janeiro de 2012. Dispõe sobre o exercício das atividades profissionais de Cabeleireiro, Barbeiro, Esteticista, Manicure, Pedicure, Depilador e Maquiador. Diário Oficial da União. 19 jan 2012; Seção 1.

Carvalho MFP, Tidei R, Ribeiro FAQ. Surdez Súbita em Aids. Rev Brasileira Otorrinolaringologia. 2001;67:249-51.

Centers for Disease Control. Recommendations for prevention of HIV transmission in health-care settings. MMWR, v. 36, n.2s, p.3-17, 21 de agosto de 1987 [acesso 15 fev 2012].

Disponível

em: http://wonder.cdc.gov/wonder/prevguid/p0000318/P0000318.asp

Centers for Disease Control. Update: universal precautions for prevention of transmission of human imunodeficiency virus, hepatitis B virus, and other bloodborne pathogens in health-care setting. MMWR, v. 37(24), p. 378-388, 24 de $\begin{array}{lllllll}\text { jun de } & 1988 & 1987 & \text { [acesso } & 15 & \text { fev } & 2012]\end{array}$ em: $\quad$ http://www.cdc.gov/mmwr/preview/mmwrhtml/00000039.htm

Center for Disease Control and Prevention. Recommendations and Reports. Prevention and control of Infections with hepatitis vírus in correcitonal settings. Morbidity and Mortality Weekly Report. 2003; 52:1.

Christo PP. Alterações cognitivas na infecção pelo HIV e Aids. Rev Assoc Med Bras. 2010;56(2):242-7. 
Eduardo MBP, Miranda ICS. Vigilância Sanitária. São Paulo: Faculdade de Saúde Pública da USP; 1998. v.8. (Série Saúde \& Cidadania).

Engelmann AI, Daí AA, Miura CSN, Bremm LL, Ceranto DCFBoleta. Avaliação dos procedimentos realizados por cirurgiões dentistas da região de Cascavel-PR visando ao controle da biossegurança. Odontol. Clín.-Cient, Recife, 2010;9(2): 161-165.

Ferreira CT, Silveira TR. Hepatites virais: aspectos da epidemiologia e da prevenção. Rev. Bras. Epidemiol. 2004;7(4):473-87.

Gil AC. Métodos e técnicas da pesquisa social. ( $5^{\text {a }}$ edição). São Paulo: Editora Atlas S.A; 2007.

Griffith R, Tengnah C. Public health: Legal regulation of tattooing and body art. $\mathrm{Br} J$ Community Nurs. 2005;10(12):575-79.

Hellard M, Campbell A, Mackintosh A, Ridge A, Bowden S. Investigation of infection control practices and knowledge of hepatitis $\mathrm{C}$ among body-piercing practitioners. Am J Infect Control. 2003;31:215-20.

Hepworth J, Murtagh M. Correct procedures and cutting corners: a qualitative study of women's occupational health and safety in a beauty therapy industry. Aust $N Z J$ Public Health. 2005;29(6):555-7.

IBGE - Instituto Brasileiro de Geografia e Estatística. Cidades. [acesso em 13 de mar de 2012]. Disponível em: http://www.ibge.gov.br/cidadesat/topwindow.htm?1

Isihi CMA. Avaliação das condições de biossegurança e percepção de risco de tatuadores e perfuradores corporais em relação à infecção pelos vírus das hepatites B e C, no Município de São Paulo [dissertação de mestrado]. São Paulo: Coordenadoria de Controle de Doenças da Secretaria de Estado da Saúde; 2010. 
Johnson IL, Dwyer JJM, Rusen ID, Shahin R, Yaffe B. Survey of infection control: procedures at manicure and pedicure establishments in North York. Rev Can Santé Publique. 2001;92(2):134-7.

Lazzarotto A, Reichert MT, Venker C, Kramer AS, Sprinz E. HIV/aids e meia idade: avaliação do conhecimento de indivíduos da região do Vale dos Sinos (RS), Brasil. Ciênc Saúde Coletiva. 2010;15(1):1185-90.

Leal CLV; Catrib AMF. O corpo, a cirurgia estética e a Saúde Coletiva: um estudo de caso. Rev Ciência \& Saúde Coletiva. 2010;15(1):77-86.

Lopes MHBM, Moromizato SS, Veiga JFFS. Adesão as medidas de precauçãopadrão: relato de experiência. Rev Latino Am Enferm. Out 1999;7(4):83-8.

Mariano A, Mele A, Tosti ME, Parlato A, Gallo G, Ragni P et al. Role of beauty treatment in the spread of parenterally transmitted hepatitis viruses in Italy. J Med Virol. 2004;74:216-20.

Minayo MCS. O desafio do conhecimento. Pesquisa Qualitativa em Saúde. $\left(8^{\text {a }}\right.$ edição). São Paulo: Hucitec; 2004.

Minayo MCS, Sanches O. Quantitativo - Qualitativo: oposição ou Complementariedade? Caderno de Saúde Pública. Jul/Set. 1993;9(3):239-262,.

Ministério da Saúde, Departamento de DST, Aids e Hepatites Virais. [acesso em: 11 jun 2010]. Disponível em: http://www.aids.gov.br/pagina/formas-de-contagio

Ministério do Trabalho e Emprego. Portaria n 3214 de 08 de junho de 1978. Aprova as Normas Regulamentadoras Normas Regulamentadoras - NR - co 
capítulo V, título II, da Consolidação das Leis do Trabalho, relativas a Segurança e Medicina do Trabalho. Diário Oficial da União 06 jun 1978; Suplemento.

Ministério da Saúde, Secretaria de Assistência à Saúde. Processamento de Artigos e Superfícies em Estabelecimentos de Saúde. 2a ed. Brasília, DF; 1994. [acesso em: 01 out 2010]. Disponível em: http://bvsms.saude.gov.br/bvs/publicacoes/superficie.pdf

Ministério da Saúde, Secretaria de Políticas de Saúde. Coordenação Nacional de DST e AIDS. Controle de infecções e a prática odontológica em tempos de AIDS: manual de condutas. Brasília, DF; 2000. acesso [12 set 2011]. Disponível em: http://cfo.org.br/wp-content/uploads/2009/10/manual_conduta_odonto.pdf

Ministério da Saúde, Secretaria de Assistência à Saúde. Coordenação Geral das Unidades Hospitalares Próprias do Rio de Janeiro. Orientações gerais para Central de Esterilização. Brasília, DF; 2001 [acesso em 12 set 2011]. Disponível em: http://www.saude.mt.gov.br/portal/controleinfecco-

$\underline{\mathrm{cO}-}$

es/documento/doc/orientacoes_gerais_para_central_de_esterilizacao_de_materiais_2 001.pdf

Ministério do Trabalho e Emprego. Classificação Brasileira de Ocupações. Descrição. 2002a. [acesso em 14 abr 2010]. Disponível em: http://www.mtecbo.gov.br/cbosite/pages/pesquisas/BuscaPorTituloResultado.jsf

Ministério do Trabalho e Emprego. Classificação Brasileira de Ocupações. Relatório da Família. 2002b. [acesso em 14 abr 2010]. Disponível em: http://www.mtecbo.gov.br/cbosite/pages/pesquisas/ResultadoFamiliaParticipante s.jsf 
Ministério da Saúde. Secretaria de Vigilância em Saúde. Hepatites Virais: O Brasil está atento. $3^{\mathrm{a}}$ ed. Brasília, DF; 2008.

Naressi SC, Akama CM, Silva LMP, Siviero M. Análise das formas de esterilização e do meio de controle empregados pelos cirurgiões-dentistas de São Jose dos Campos SP. Revista de Odontologia da Unesp. 2004.33(4):169-74.

Noce CW, Júnior AS, Ferreira SMS. Panorama mundial da epidemia pelo HIV/AIDS: aspectos sociais e lesões bucais. DST - J Bras Doenças Sex Transm. $2005 ; 17(4): 301-305$.

Oberdorfer A, Wiggers JH, Bowman J, Lecathelinais C. Infection control pratices among tattooists and body piercers in Sydney, Australia. Am J Infect Control. 2003a; 31(8):447-56.

Oberdorfer A, Wiggers JH, Considine RJ, Bowman J, Cockburn Jill. Skin penetration operators knowledge and attitudes towards infection control. Am J Health Behav. 2003b;27(2):125-134.

Oliveira ACDS. Estudo da estimativa de prevalência das hepatites B e C e da adesão às normas de biossegurança em manicures e/ou pedicures do município de São Paulo [dissertação de doutorado]. São Paulo: Coordenadoria de Controle de Doenças da Secretaria de Estado da Saúde; 2009.

Oliveira ACDS, Focaccia R. Survey of hepatitis B and C infection control: procedures at manicure and pedicure facilities in São Paulo, Brazil. Braz J Infect Dis. 2010; 14(5): 502-507.

Oppermann CM, Pires LC. Manual de biossegurança para serviços de saúde. Porto Alegre. PMPA/SMS/CGVS; 2003 [acesso em 03 jan 2012]. Disponível em: http://www.bvsde.paho.org/bvsacd/cd49/manualbiossegurancaa.pdf 
Pereira Filho WR, Barroco R. Gestão da qualidade na indústria farmacêutica. In: OLIVEIRA OJ (org.) Gestão da qualidade: tópicos avançados. São Paulo: Thompson; 2004.

Prefeitura Municipal de São Paulo. COVISA. Orientações sobre prevenção de riscos à saúde em salões de beleza. [acesso em: 20 abr 2011]. Disponível em: http://www.prefeitura.sp.gov.br/cidade/secretarias/upload/chamadas/saloes_de_belez a_1279129626.pdf

Prefeitura Municipal de São Paulo. COVISA. Beleza com Segurança. Guia técnico para profissionais. [acesso em: 20 abr 2011]. Disponível em: http://www.prefeitura.sp.gov.br/cidade/secretarias/upload/beleza_com_seguranca_at ualizado_1259679281.pdf

Prefeitura Municipal de Santo André. Guia de embelezamento saudável. [acesso em: 20 abr 2011]. Disponível em: http://www.santoandre.sp.gov.br/bnews3/images/multimidia/programas/cartilha\%20 para\%20pdf\%20aberta.pdf

Raymond MJ, Phyllis PL, Linda HL. Infection control among professional tattooists in Minneapolis and St. Paul, MN. Public Health Rep. 2001;116,249-56.

Sanderson BF, Bitencourt CF, Silva FF, Balconil GT, Brito TLC, Duarte MMMF. Dermopigmentação uma alternativa estética e reparadora [acesso em: 26 nov 2010]. Disponível em: HTTP://ulbra.br/Santamaría/eventos/jornada/2009/JPE2009/Eco125647704.pdf

São Paulo (Estado). Lei Estadual 10083 de 23 de setembro de 1998. Dispõe sobre o Código Sanitário do Estado de São Paulo. . Diário Oficial do Estado. 24 set 1998; Seção I. 
São Paulo (Estado) Secretaria de Saúde. Centro de Vigilância Sanitária. Portaria CVS - $\mathrm{n}^{\circ} 11$, de 16 de agosto de 1993. Dispõe sobre o funcionamento dos estabelecimentos que exercem atividade de Podólogo (Pedicuro).

São Paulo (Estado), Secretaria de Saúde. Resolução SS no 374, de 15 de dezembro de 1995. Altera a norma técnica sobre a organização do centro de material e noções de esterilização. 1995. Diário Oficial do Estado. 16 dez 1995; Seção I.

São Paulo (Estado), Secretaria de Saúde. Centro de Vigilância Sanitária. Resolução SS - 196 de 29 de dezembro de 1998. Roteiros e guias de inspeção em vigilância sanitária. Diário Oficial do Estado. 31 dez 1998; Seção I.

São Paulo (Estado), Secretaria de Saúde. Centro de Vigilância Sanitária. Portaria CVS - $\mathrm{n}^{\circ} 12$, de 30 de julho de 1999. Dispõe sobre os estabelecimentos de interesse à saúde denominados Gabinetes de Tatuagem e Gabinetes de Piercing e dá providências correlatas. Diário Oficial do Estado. 31 jul 1999; Seção I.

São Paulo (Estado), Secretaria da Saúde. Centro de Vigilância Epidemiológica Prof Alexandre Vranjac. Guias de orientações técnicas hepatites B e C. 2002 [acesso em 03 jan 2011]. Disponível em: ftp://ftp.cve.saude.sp.gov.br/doc_tec/outros/hepa_guia03.pdf

Silva LFM, Albuquerque CMT, Ferreira LOC. Informações sobre as práticas do processo de esterilização dos tatuadores e "piercers" do Recife - PE 2006. Revisa. 2007; 3(1/2/3);313-9.

Souza MF. Os usos da tatuagem: o corpo como tela de significados. Rev Brasileira de Psicoterapia. 2001;3(3):257-74.

Weber AM. Evaluation of potential bloodborne pathogen exposures among body piercers. Appl Occup Environ Hyg. 2001;16:925-35. 
Worp J, Boonstra A, Coutinho RA, Hoek JAR. Tattooing, permanent makeup and piercing in Amsterdam; guidelines, legislation and monitoring. Euro Surveill. 2006;11(1):34-6. 


\section{ANEXOS}

\section{Anexo 1}

\section{Questionário}

1. Tipo de Profissional

\section{( ) Manicure e/ou pedicure \\ ( ) Tatuagem \\ ( ) Piercing \\ ( ) Maquiagem definitiva}

Data: ___ I _ _ I _ Ientificação:

2. Cadastro

( ) Possui cadastro na VISA

( ) Não possui cadastro na VISA

3. Sexo

\section{( ) Masculino \\ ( ) Feminino}

4. Idade
( ) 18 a 25 anos
( ) 26 a 40 anos
( ) 41 a 55 anos 


\section{( ) 56 a 59 anos}

( ) $>59$ anos

\section{Escolaridade}

\section{( ) Analfabeto}

( ) Ensino Fundamental incompleto

( ) Ensino Fundamental completo

( ) Ensino Médio incompleto

( ) Ensino Médio completo

( ) Ensino Superior incompleto

( ) Ensino Superior completo

\section{Tempo de Profissão}
$(\quad)<$ de 1 ano
( ) De 1 a 2 anos
( ) De 2 a 3 anos
( ) De 3 a 5 anos
( ) De 6 a 10 anos
( ) $>$ de 10 anos

7. Você fez algum curso profissionalizante, capacitação ou atualização para desenvolver esta atividade ?

\section{( ) Sim. Duração? \\ ( ) Não}

8. Você acredita que pode adquirir (pegar) alguma doença de seus clientes durante sua atividade profissional?

( ) Sim. Qual (is)? 


\section{( ) Não \\ ( ) Não sabe}

9. Você acredita que pode transmitir (passar) alguma doença para seus clientes durante sua atividade profissional?

\section{( ) Sim. Qual (is)? \\ ( ) Não \\ ( ) Não sabe}

10. Você sabe o que é HIV/Aids ?

( ) Sim. Descreva?

( ) Não

11. Você sabe o que é hepatite ?

( ) Sim. Descreva?

( ) Não

12. Você sabe como são transmitidas HIV/Aids e hepatite?

\section{( ) Sim. Como?}

( ) Não

13. Você sabe como se prevenir para não adquirir estas doenças?
( ) Sim. Como?
( ) Não 
14. Durante seu trabalho, você entrou em contato com sangue de seus clientes sem estar usando luvas?

( $\quad$ Sim. O que fez ao entrar em contato com sangue (conduta)?
( ) Não
( ) Não sabe

15. Você lava as mãos entre um cliente e outro?

( ) Sim, entre todos clientes

( ) sim, às vezes

( ) não lava

16. Você usa equipamento de proteção individual?

( ) Sim.

( ) Não

17. Se "sim", qual equipamento você usa?

\section{( ) Luvas descartáveis}

( ) Máscara

( ) Luvas de borracha para a lavagem de instrumentais

( ) Avental ou uniforme

( ) Óculos de proteção

Por quê?

18. Você sabe o que é esterilização dos instrumentais?

( ) Sim. Descreva:

( ) Não 
19. Qual método você utiliza para a esterilização dos instrumentais (alicates, espátulas, cortador de unha e etc.).

( ) Autoclave (Temperatura:__ tempo:__ $)$
( ) Estufa (Temperatura:___tempo:__ )
( ) Outros. Qual?
( ) Não realiza esterilização

20. Os materiais de uso único (lâminas para remoção de pelos, palitos, lixas, etc.) são desprezados após utilizados?

\section{( ) $\operatorname{Sim}$ \\ ( ) Não}


Anexo 2

\section{ROTEIRO OBSERVACIONAL}

\section{Estrutura Física}

Existe pia para higienização das mãos dos profissionais próximo ao local de atendimento ao cliente?

( ) Sim ( ) Não
Existe sabão líquido e toalha descartável para a higienização das mãos dos profis-
sionais?
( ) $\operatorname{Sim}$
( ) Não

Existe álcool em gel para higienização das mãos dos profissionais?

( ) $\operatorname{Sim}$ ( ) Não

Existe área dotada de pia exclusiva para a limpeza dos instrumentais?
( ) $\operatorname{Sim}$
( ) Não

Existe área específica para a esterilização dos instrumentais?
( ) $\operatorname{Sim}$
( ) Não

O piso e a parede são de material liso, lavável, impermeável e de fácil limpeza?
( ) $\operatorname{Sim}$
( ) Não

\section{Desinfecção, limpeza e esterilização dos instrumentais}


Realiza desinfecção prévia dos instrumentais por meio de imersão em solução apropriada?

( ) Sim ( ) Não
Os instrumentais usados são colocados em caixa plástica lavável sinalizada como
contaminados?

( ) Sim ( ) Não

Realiza limpeza mecânica dos instrumentais?

( ) $\operatorname{Sim} \quad$ ( ) Não

Possui registros de manutenção preventiva e corretiva da autoclave e/ou estufa?
( ) $\operatorname{Sim}$
( ) Não

Realiza controle biológico ou químico do processo de esterilização?
( ) $\operatorname{Sim}$
( ) Não

Utiliza invólucros e/ou caixas identificados com data da esterilização e prazo de validade?

( ) Sim ( ) Não

Os instrumentais esterilizados são acondicionados e armazenados de forma a garantir a manutenção da esterilização?
( ) $\operatorname{Sim}$
( ) Não

O equipamento esterilizador é aberto durante o processo de esterilização?
( ) $\operatorname{Sim}$
( ) Não

Se o equipamento esterilizador for aberto o processo de esterilização é reiniciado? 
A estufa ou forninho possui termômetro externo e termostato?

( ) $\operatorname{Sim} \quad$ ( ) Não

A embalagem e/ou caixa é aberta somente no momento em que os instrumentais serão utilizados?

( ) $\operatorname{Sim} \quad$ ( ) Não

Existe rotina por escrito do processo de esterilização?

( ) Sim ( ) Não

Os materiais como agulhas, brincos, piercings e outros usados para perfurar 0 corpo são estéreis?
( ) $\operatorname{Sim}$
( ) Não

Materiais estéreis são armazenados dentro do prazo de validade de esterilização?

( ) $\operatorname{Sim} \quad$ ( ) Não

\section{Resíduos}

Existe lixeira com tampa e pedal para descarte de luvas de procedimentos, algodão e etc.?

( ) $\operatorname{Sim} \quad$ ( ) Não

Existe recipiente rígido, resistente à punção para o descarte de agulhas e objetos perfurocortantes?

( ) Sim ( ) Não 
Os resíduos infectantes são coletados por empresa de coleta especial?

( ) Sim ( ) Não

O lixo comum é coletado pela empresa de limpeza urbana?

( ) Sim ( ) Não

\section{Itens gerais}

A limpeza dos mobiliários e ambientes é realizada diariamente?

( ) Sim ( ) Não

Possuem instrumentais (alicates) em quantidade sufficiente de forma a garantir a esterilização deles a cada uso?

( ) Sim ( ) Não




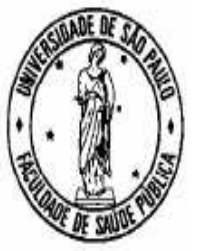

UNIVERSIDADE DE SÃO PAULO

FACULDADE DE SAÚDE PÚBLICA

Seção de Pós-Graduação

Av. Dr. Arnaldo, 715 - CEP 01246-904 - São Paulo - Brasil

Fone: (55-11) 3061-7790 - Fone/Fax: (55-11) $3061-7798$

e-mail: posgrad@ fsp.usp.br

\section{TERMO DECONSENTIMENTO LIVRE E ESCLARECIDO}

Procedimentos de biossegurança adotados por profissionais prestadores de serviços de manicure, pedicure, tatuagem, piercing e maquiagem definitiva no município de Jacareí-SP

Pesquisador Responsável: Andréia Ferreira Diniz Cortelli

Este projeto tem o objetivo de conhecer a forma de trabalhar e como é realizado o controle de infecção por profissionais de serviços de manicure, pedicure, tatuagem, piercing e maquiagem definitiva no município de Jacareí.

Este estudo será utilizado para a pesquisa de mestrado da farmacêutica Andréia Ferreira Diniz Cortelli.

O estudo é de grande importância para o município de Jacareí, pois fornecerá ao Sistema Único de Saúde dados e informações para a realização de ações educativas e preventivas direcionadas aos serviços de embelezamento, promovendo a saúde pública.

Para tanto será necessário que o profissional entrevistado responda ao questionário e permita que a pesquisadora observe seus procedimentos durante suas atividades e também o local onde ele trabalha. Após a entrevista será entregue material educativo juntamente com a realização de uma breve orientação pela entrevistadora.

Durante a execução do projeto o risco do entrevistado se sentir envergonhado é mínimo, pois as informações obtidas através dessa pesquisa 
serão confidenciais ao Prof. Dr. Glavur Rogério Matté e a farmacêutica Andréia Ferreira Diniz Cortelli, sendo garantido o sigilo sobre a identificação dos participantes, pois os dados não serão divulgados de forma a possibilitar esta identificação. O questionário e o roteiro de observação serão identificados apenas pelas iniciais do nome do entrevistado. Na apresentação da dissertação de mestrado, nenhum participante do estudo será identificado.

O entrevistado receberá uma cópia deste termo onde constam o telefone da pesquisadora e o endereço institucional, podendo tirar suas dúvidas sobre o estudo e sua participação, agora ou a qualquer momento.

Após ler e receber explicações sobre a pesquisa, e ter meus direitos de:

1. receber resposta a qualquer pergunta e esclarecimento sobre os procedimentos, riscos, benefícios e outros relacionados à pesquisa;

2. retirar o consentimento a qualquer momento e deixar de participar do estudo;

3. não ser identificado e ser mantido o caráter confidencial das informações relacionadas à privacidade.

4. procurar esclarecimentos com a pesquisadora Andréia Ferreira Diniz Cortelli pelo telefone 12 3961-1882 ou com o Comitê de Ética em Pesquisa da Faculdade de Saúde Pública da Universidade de São Paulo, no telefone 11 30617779 ou Av. Dr. Arnaldo, 715 - Cerqueira César, São Paulo - SP, em caso de dúvidas ou notificação de acontecimentos não previstos.

Declaro estar ciente do exposto e desejar participar do projeto.

São Paulo, de de

Nome do sujeito:

Assinatura:

$\mathrm{Eu}$, Andréia Ferreira Diniz Cortelli, declaro que forneci todas as informações referentes ao projeto ao participante.

Data: 
Anexo 4

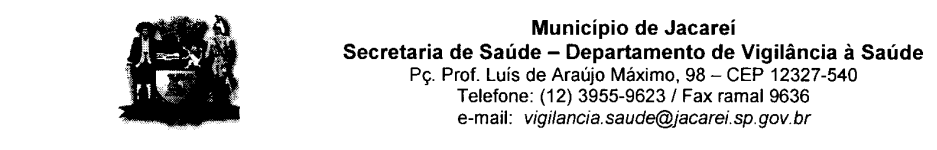

Jacaré́, 10 de setembro de 2010

\section{Declaração}

Declaramos que a servidora Andréia Ferreira Diniz Cortelli, matrícula $\mathrm{n}^{\circ} 23792-4$ lotada no Departamento de Vigilância à Saúde no cargo de Farmacêutica, aluna do mestrado na Faculdade de Saúde Pública da Universidade de São Paulo da área de concentração Vigilância Sanitária, não realiza inspeções sanitárias (fiscalização) nos serviços de embelezamento: salões de beleza, manicure, pedicure, tatuagem, piercing e maquiagem definitiva.

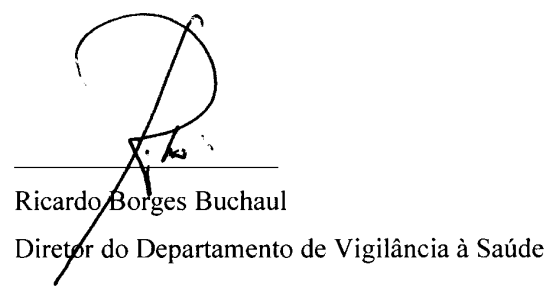

DVS - Departamento de Vigilância à Saúde 


\section{Anexo 5}

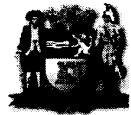

Municipio de Jacarei Vento de Vigilância à Saúde Ç. Prof. Luis de Araújo Máximo, 98 - CEP 12327-540

Telefone. (12) 3955-9623 / Fax ramal 9636

Jacareí, 10 de setembro de 2010

\section{Autorização}

O Departamento de Vigilância à Saúde do município de Jacareí autoriza a pesquisadora Andréia Ferreira Diniz Cortelli, aluna do mestrado da Faculdade de Saúde Pública - Universidade de São Paulo, realizar a pesquisa intitulada: "Procedimentos de biossegurança adotados por profissionais de serviços de manicure, pedicure, tatuagem, piercing e maquiagem definitiva no município de Jacareí" na área de sua competência municipal.

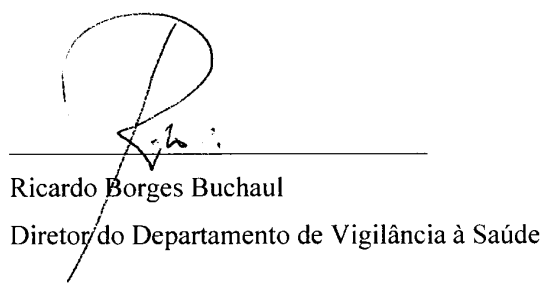

DVS - Departamento de Vigilância à Saúde 


\section{Anexo 6 \\ Orientações sobre prevenção de riscos à saúde em serviços de embelezamento}

Os serviços de manicure, pedicure, tatuagem, piercing, maquiagem definitiva devem ser seguros.

Conheça alguns cuidados que podem proteger a saúde dos profissionais e clientes:

\section{Ambiente}

O local deve ser impo e organizado, com boa iluminação e ventilação. Os banheiros devem ter sabonete líquido, papel toalha, lixeira com tampa acionada por pedal.

\section{Produtos e equipamentos}

Os produtos e equipamentos utilizados devem possuir registro ou notificação junto ao Ministério da Saúde, nome e endereço do fabricante e data de validade.

As lixas e lâminas para remoção de pêlos devem ser individuais e descartadas após o uso.

As toalhas devem ser limpas e de uso individual.

\section{Limpeza e Esterilização dos materiais}

Alicates, espátulas e outros materiais de metais devem ser lavados e esterelizados após cada uso. Após secos, devem ser embalados apropriadamente para o processo de esterilização. Na embalagem deve constar a data da esterilização e o nome de quem preparou o material.

A esterilização dos materiais elimina microorganismos que podem causar doenças como Aids, Hepatites B e C, micoses e outras infecções.

A esterilização pode ser realizada em estufa ou autoclave. 
$\mathrm{Na}$ estufa é necessário que os materiais permaneçam a $170^{\circ} \mathrm{C}$ por 1 hora ou a $160^{\circ} \mathrm{C}$ por 02 horas. É necessário esperar a estufa atingir a temperatura ideal, e só então começar a marcar o tempo.

A estufa não pode ser aberta durante o processo de esterilização.

Os materiais devem ser armazenados em local limpo e seco. A embalagem deve ser aberta somente no momento do uso.

O profissional deve lavar as mãos antes e após de atender cada cliente e usar equipamentos de proteção individual, como luvas descartáveis, avental, etc. 